PALEO

Revue d'archéologie préhistorique

$24 \mid 2013$

Varia

\title{
The Columbian mammoths from the Upper Pleistocene of Hot Springs (South Dakota, United States)
}

Les mammouths de Colomb du Pléistocène supérieur de Hot Springs (Dakota du Sud, Etats-Unis)

\section{Sophie Louguet-Lefebvre}

\section{OpenEdition}

\section{Journals}

\section{Electronic version}

URL: http://journals.openedition.org/paleo/2861

DOI: 10.4000/paleo.2861

ISSN: 2101-0420

\section{Publisher}

SAMRA

\section{Printed version}

Date of publication: 15 December 2013

Number of pages: 149-171

ISSN: $1145-3370$

\section{Electronic reference}

Sophie Louguet-Lefebvre, «The Columbian mammoths from the Upper Pleistocene of Hot Springs (South Dakota, United States) », PALEO [Online], 24 | 2013, Online since 10 September 2015,

connection on 07 July 2020. URL : http://journals.openedition.org/paleo/2861 ; DOI : https://doi.org/ 10.4000/paleo.2861

This text was automatically generated on 7 July 2020 .

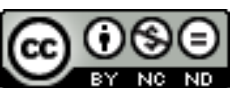

PALEO est mis à disposition selon les termes de la licence Creative Commons Attribution - Pas d'Utilisation Commerciale - Pas de Modification 4.0 International. 


\section{The Columbian mammoths from the Upper Pleistocene of Hot Springs (South Dakota, United States)}

Les mammouths de Colomb du Pléistocène supérieur de Hot Springs (Dakota du Sud, Etats-Unis)

Sophie Louguet-Lefebvre

I am thanking Dr. Larry D. Agenbroad, Emeritus Professor of Geology at the University of Flagstaff in Arizona and director of the Mammoth Site, as well as the entire team of the museum, for inviting me to study this exceptional collection of fossil of Proboscidea and for welcoming me so warmly, on the site as in their research laboratory. A big thank you to Gary Haynes for his kindness and valuable data. Finally, thank you to William Devriendt (cad-dap Douai) for this new illustration, here the reconstitution of Hot Springs (fig. 2).

\section{1 - Introduction}

1 Discovered by chance in 1974 during the construction work of a housing scheme, the paleontological site of Hot Springs in South Dakota was completely preserved. If other sites have revealed remains of mammoths in the region, such as the Upper Palaeolithic site of Lange Fergusson also known worldwide (two butchered mammoths associated with Clovis points within an ancient swampland, Hannus 1989), the Site of Hot Springs is undoubtedly the most impressive judging by the concentration of skeletons of mammoths found in situ (fig. 1). Indeed, the site shows a significant accumulation of remains belonging to a typical upper Pleistocene fauna, largely dominated by the Columbian mammoths that were roaming the Great Plains of North America about \pm 26,000 BP (average 14C dates, Laury 1990).

2 The lake fed by a hot spring and the green bordering vegetation, typical of a swamp, would have been especially attractive during the glacial periods for animals and especially for mammoths whose daily needs must have been around at least 200 litres 
of water. The spring would have been a formidable trap for animals that ventured into this swamp with steep and slippery banks ending as a swallow hole in its submerged part. Thus, many animals were caught into the trap that proved fatal to the megaherbivores such as mammoths.

Knowing the origin of an elephantidae bone assemblage is far from easy. Thus, the use of a solid frame of reference in terms of natural mortality, excluding the anthropogenic factor, is essential for the analysis of remains from paleontological sites. This requires knowledge of the social structures of present-day populations of elephants as well as of the mortality profiles issued from fossil species from purely paleontological sites. The aim of this study is to examine the possible circumstances of the death of the mammoths on the site given the analysis of the newly established mortality profile.

Figure 1 - Location of the main Mammuthus columbi sites.

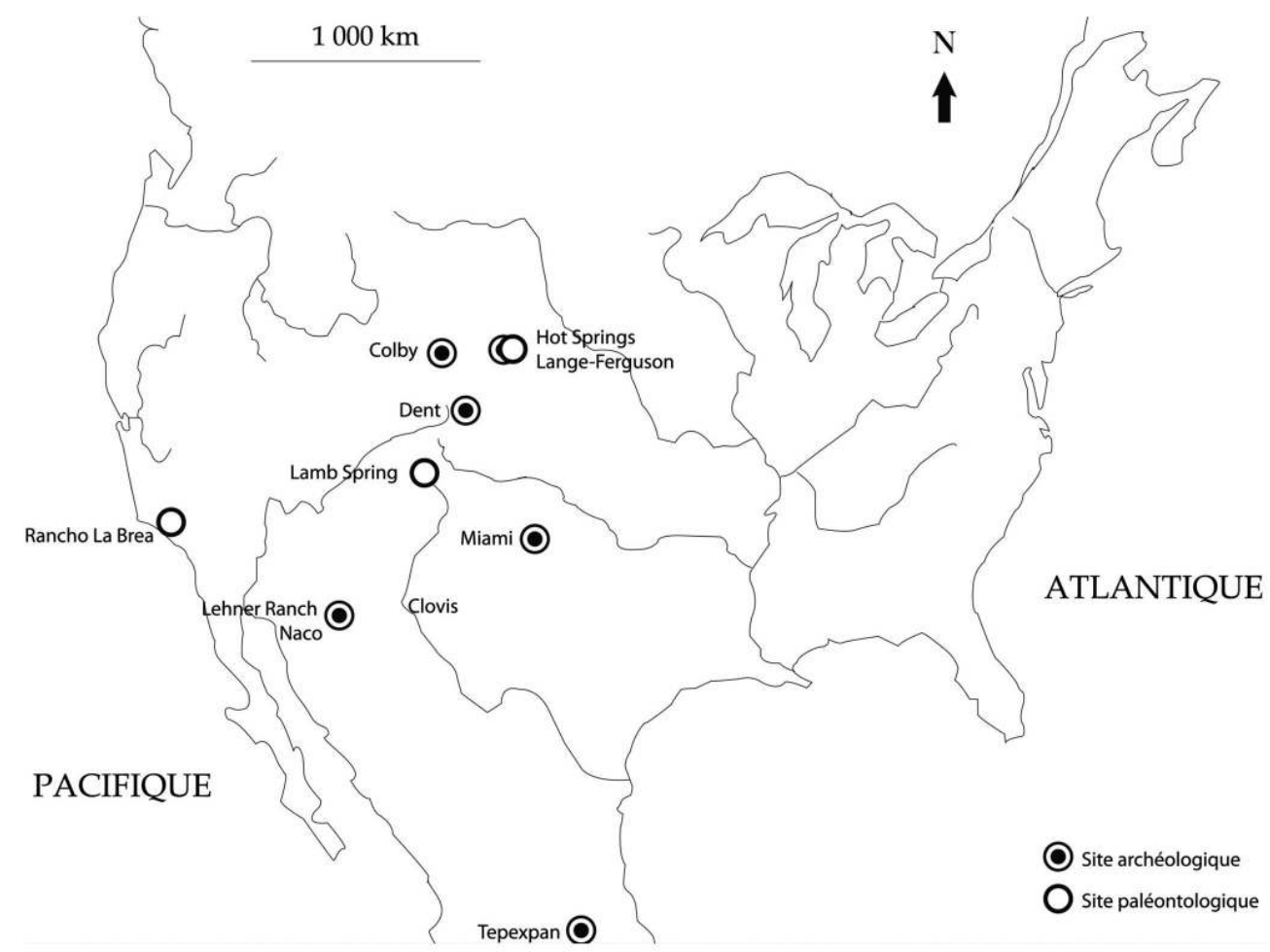

\section{2 - Presentation of the site}

\section{1 - Location and geological context}

The site is located south of the Black Hills (GPS 43.4291, -103.494774). It was created out of the collapse $\pm 26,000$ years BP ago (Laury 1990) of the ceiling of an underground cave (fig. 2). The $40 \mathrm{~m}$ long elliptical depression thus formed was presenting a wall whose inclination ranged from $60^{\circ}$ to the horizontal and a depth varying from $14 \mathrm{~m}$ for the south-western portion to $21 \mathrm{~m}$ in the north-eastern part. There, a hot artesian spring supplied over time a lake whose surface temperature was around 35 to $40^{\circ} \mathrm{C}$, as proven by malacological, pollen and fish analyses (Agenbroad 1990). 


\section{2 - Stratigraphy}

5 The stratigraphic filling of the bowl, born from the collapse of the karst, is a superposition of laminated fine-grained sediments layers, ranging from layers of clay to coarse sand layers resulting from the erosion and weathering of the rock face and of the gravel making the ancient terrace of the neighbouring palaeoriver. The skeletal remains were unearthed from the three major phases of sedimentation of the sequence, and even if the excavation is still in progress, the main areas have already been tested in depth. The trap would have operated for about 300 to 700 years before its total filling by the sediments (Laury 1990).

6 Swaying rotting carcasses and the movements of underwater gravity are factors not to be overlooked in the process of deposition of the bone remains. Indeed, they have actively contributed to the disarticulation and specific location of some specimens. Whatever the sedimentation stage considered, the most notable density of remains is located along the ancient banks. The bones, all recorded in three dimensions, are concentrated less than $6 \mathrm{~m}$ away from the wall (Laury 1990, fig. 2). It is possible that the artesian flow contributed to deprive the central part of the filling of remains. The north-eastern portion of the deposit has a high concentration of isolated bone remains from a sandy matrix, a consequence of the artesian flow, whereas the south-western part presents elements in anatomical connection set in a context of laminated layers of clay and silt, suggesting a much more moderate underwater energy. Thus, most of the carcasses were partially disarticulated before being dragged down to the bottom of the sunken bank and afterwards buried under sediments. The most remarkable specimen unearthed is the complete post- cranial skeleton of an adult female preserved in situ in anatomical connection ( $\left.\mathrm{n}^{\circ} 13 \mathrm{~S} 23 \mathrm{~W}\right)$.

\section{3 - Preservation of the archaeological remains}

7 The gradual erosion of the banks has allowed the excellent preservation of all the bones. Even the smallest and most delicate, such as the hyoid bone or sesamoid bones were preserved by the rapid covering by the sediments of the anatomical elements just discomposed. In addition, the natural origin of the fracturing of fresh bone, without impact or repercussion, highlighted on eleven Elephantidae bones, leaves little doubt. This is corroborated by the absence of anthropogenic traces on the site, as Agenbroad LD (1989) already concluded. It is possible that the still fresh bones broke under the weight of the mammoths in difficulty on the banks.

\section{4 - List of fauna}

While the overwhelming overrepresentation of Columbian mammoths (Mammuthus columbi) tends to obscure the diversity of the fauna documented at Hot Springs, many animal species belonging to mammals, birds, fish, amphibians and invertebrates have already been inventoried (Agenbroad, Mead, 994, updated on http:// www.mammothsite.com).

9 Among the other large mammals present at the site, the following were uncovered: woolly mammoths (Mammuthus primigenius), ancient camels (Camelops hesternus), llamas (Hemiauchenia sp.), pronghorn antelopes (Antilocapra americana) and finally 
five carnivores: giant short-faced bears (Arctodus simus), wolves (Canis lupus), coyotes (Canis latrans), badgers (Taxidea taxus) and another smaller mustelid mink or ferretlike (Mustela sp.). Two species of lagomorphs have also been found, namely Townsend hare (Lepus cf. Townsendii) and a rabbit (Sylvilagus sp.). Insectivores are represented by the mole (Scalopus aquaticus), while a number of rodents is consistently enriching the faunal list. These include first of all the prairie dogs (Cynomys ( Leucocrossuromys ) sp.), thirteen-lined ground squirrels (Spermophilus cf. tridecemlineatus) and slightly larger squirrels (Spermophilus cf. elegans or richardsonii), followed by the northern pocket gopher (Thomomys talpoides), hamsters (Neotoma cf. cinerea), mice (Peromyscus cf. maniculatus), heather voles (Phenacomys cf. intermedius) and smaller voles (Microtus sp.).

10 If it seems remarkable to have unearthed Mammuthus primigenius (represented by three individuals) and Mammuthus columbi on the same site, this does not necessarily imply that the two species coexisted. Indeed, the skeletal remains of woolly mammoths come from the upper sediments. This could indicate that they have come after the Columbian mammoths at the site (Agenbroad, Mead 1994).

Figure 2 - Hot Springs restitution, $\pm 26,000$ years BP (๔ W. Devriendt).

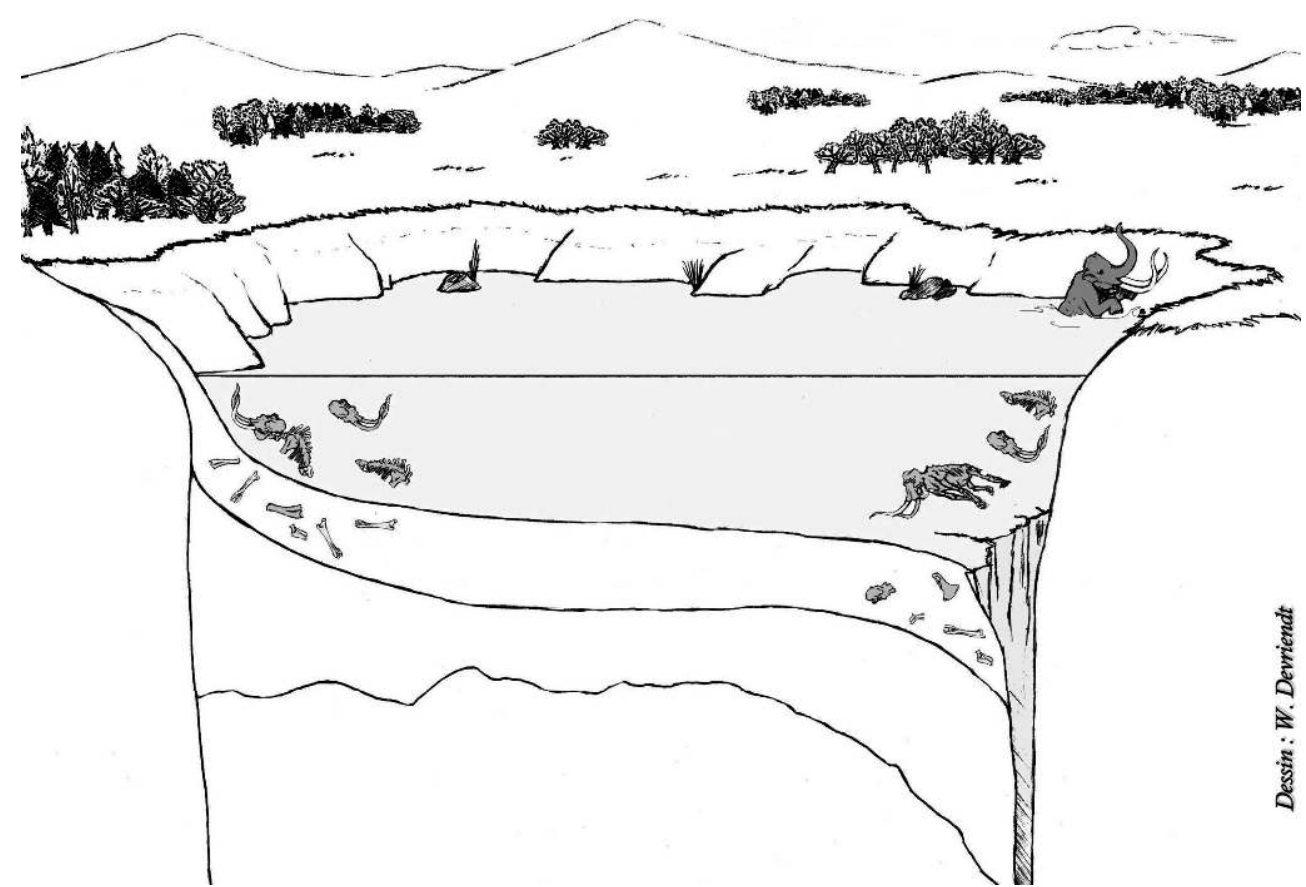

\section{3 - Palaeo-environmental analysis}

11 The pond, fed by the hot spring, was located near the southern boundary of the North American ice sheet. Its bordering lush vegetation, typical of a swamp, would have been very attractive to wildlife. The surroundings were occupied by large areas of low vegetation, steppe-type, characteristic of the relatively cold general climate, to the detriment of the forest that only persisted residually at the bottom of the valleys.

Ecological methods, based on the presence of mammals, were applied in order to come closer to the reality of the environment of the site at the time. These methods, 
ecological histograms and cenograms, have the advantage of not taking into account the quantification of the species but only their presence. The use of these tools is therefore particularly suitable for Hot Springs, which is still being excavated and whose complex sediment dynamics does not preclude a distribution of the remains by taxonomic format.

\section{1 - Ecological Histograms}

The method of compiling and interpreting different ecological histograms takes into account the systematic of each species, but also the mass, the diet and locomotive adaptation of each of them. Defined by T.H. Fleming on the Central American and North American (Fleming 1973) current mammalian communities, the method was then transposed to fossil species by P. Andrews et al. (1979) and modified by Cl. Guérin and M. Faure (1987).

The predominance of rodents in Hot Springs, followed to a lesser extent by carnivores and artiodactyls, characterizes an environment dominated by forest. However, the hegemony of the herbivores with hypsodont teeth indicates the openness of the environment (tabl. 1, fig. 3 and $4 \mathrm{a}$ and b). This diversity of vegetation cover is finally strengthened by the importance of species under a kilo, followed to a lesser extent by the under $10 \mathrm{~kg}$, coupled with the notable presence of species over $200 \mathrm{~kg}$ (Fig. 4c).

Table 1 - Legend of ecologist histograms from Hot Springs.

\begin{tabular}{|c|c|c|c|c|}
\hline Espèces & Systématique & Masses & Alimentation & Locomotion \\
\hline Mammuthus colombi & Pro & $\mathrm{H}$ & $\mathrm{HH}$ & GT u \\
\hline Mammuthus primigenius & Pro & $\mathrm{H}$ & $\mathrm{HH}$ & GT u \\
\hline Arctodus simus & $\mathrm{C}$ & G & $\mathrm{O}$ & GT u \\
\hline Camelops hesternus & $\mathrm{Ar}$ & $\mathrm{G}$ & $\mathrm{HB}$ & GT u \\
\hline Hemiauchenia sp. & $\mathrm{Ar}$ & $\mathrm{E}$ & $\mathrm{HB}$ & GT u \\
\hline Canis lupus & $\mathrm{C}$ & $\mathrm{D}$ & $\mathrm{C}$ & GT u \\
\hline Antilocapra Americana & $\mathrm{Ar}$ & $\mathrm{D}$ & $\mathrm{HH}$ & GT c \\
\hline Canis latrans & $\mathrm{C}$ & $\mathrm{D}$ & $\mathrm{C}$ & GT u \\
\hline Taxidea taxus & $\mathrm{C}$ & $\mathrm{C}$ & $\mathrm{O}$ & GT u \\
\hline Lepus cf. townsendii & A & $\mathrm{C}$ & $\mathrm{HH}$ & PT \\
\hline Cynomys (Leucocrossuromys) sp. & $\mathrm{R}$ & $\mathrm{C}$ & $\mathrm{HB}$ & PT \\
\hline Mustela cf. vison or nigripes & $\mathrm{C}$ & $\mathrm{C}$ & $\mathrm{O}$ & GT u \\
\hline Sylvilagus sp. & A & $\mathrm{AB}$ & $\mathrm{HH}$ & PT \\
\hline Spermophilus cf. elegans or richardsonii & $\mathrm{R}$ & $\mathrm{AB}$ & $\mathrm{F}$ & $\mathrm{Gr}-\mathrm{Ar}$ \\
\hline Neotoma cf. cinerea & $\mathrm{R}$ & $\mathrm{AB}$ & $\mathrm{F}$ & Fo \\
\hline Spermophilus cf. tridecemlineatus & $\mathrm{R}$ & $\mathrm{AB}$ & $\mathrm{F}$ & Gr-Ar \\
\hline Thomomys talpoides & $\mathrm{R}$ & $\mathrm{AB}$ & $\mathrm{HH}$ & Fo \\
\hline Scalopus aquaticus & I & $\mathrm{AB}$ & $\mathrm{I}$ & Fo \\
\hline Microtus sp. & $\mathrm{R}$ & $\mathrm{AB}$ & $\mathrm{HH}$ & Fo \\
\hline Phenacomys cf. intermedius & $\mathrm{R}$ & $\mathrm{AB}$ & $\mathrm{HH}$ & Fo \\
\hline Peromyscus cf. maniculatus & $\mathrm{R}$ & $\mathrm{AB}$ & $\mathrm{F}$ & Fo \\
\hline
\end{tabular}

$\mathrm{R}=$ rongeurs $; \mathrm{I}=$ insectivores $; \mathrm{Pri}=$ primates $; \mathrm{Ar}=$ artiodactyles $; \mathrm{C}=$ carnivores $; \mathrm{Per}=$ périssodactyles Pro $=$ proboscidiens $; \mathrm{A}=$ autres ordres, ici lagomorphes

$\mathrm{AB}<1 \mathrm{~kg} ; \mathrm{C}=1-10 \mathrm{~kg} ; \mathrm{D}=10-45 \mathrm{~kg} ; \mathrm{E}=45-100 \mathrm{~kg} ; \mathrm{F}=100-200 \mathrm{~kg} ; \mathrm{G}=200-1000 \mathrm{~kg} ; \mathrm{H}=>1 \mathrm{t}$

$\mathrm{I}=$ insectivores $; \mathrm{F}=$ frugivores et granivores $; \mathrm{HB}=$ herbivores brachyodontes $; \mathrm{HH}=$ herbivores hypsodontes ; $\mathrm{C}=$ carnassiers $; \mathrm{O}=$ omnivores

GTf, GTu, GTc = grands mammifères terrestres forestiers, ubiquistes, coureurs ; PT = petits mammifères terrestres $; \mathrm{Gr}-\mathrm{Ar}=$ grimpeurs et arboricoles $; \mathrm{Aq}=$ aquatiques $; \mathrm{Ae}=$ aériens, $\mathrm{Fo}=$ fouisseurs 
Figure 3 - Ideal ecological profiles, according to Péan 2001 (cf. légend table 1)

a/ Systématique

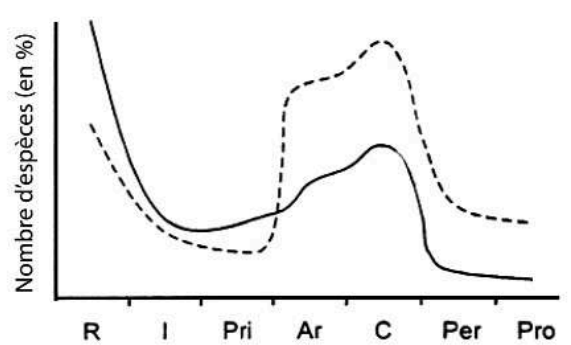

c/ Masse

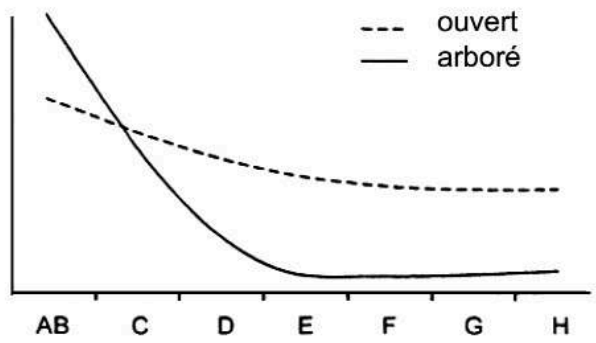

b/ Régime alimentaire

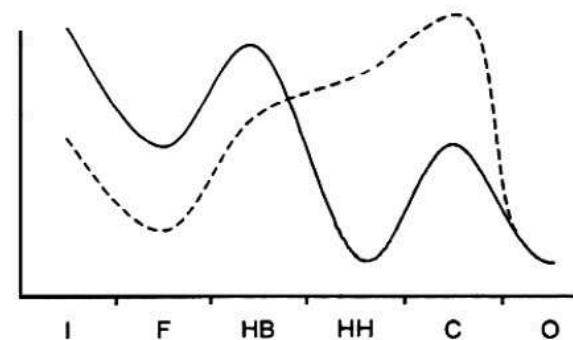

d/ Locomotion

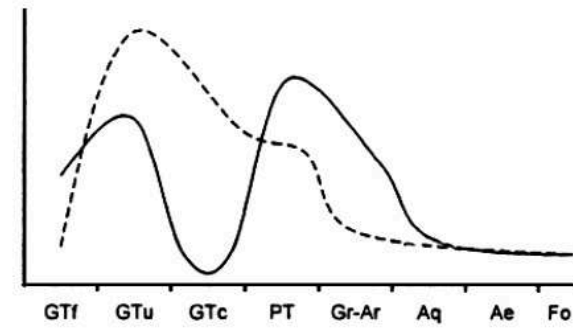

Figure 4 - Ecological profiles from Hot Springs (cf. légend table 1).

a/ Systématique

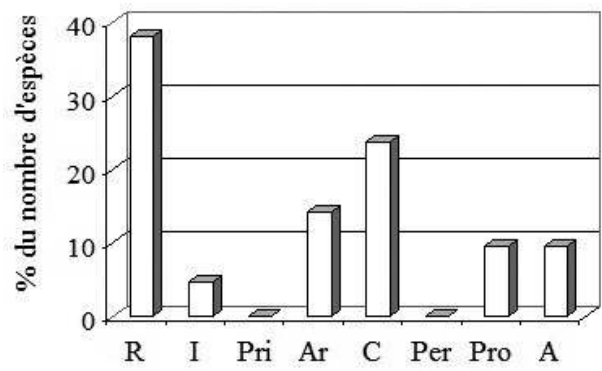

c/ Masse

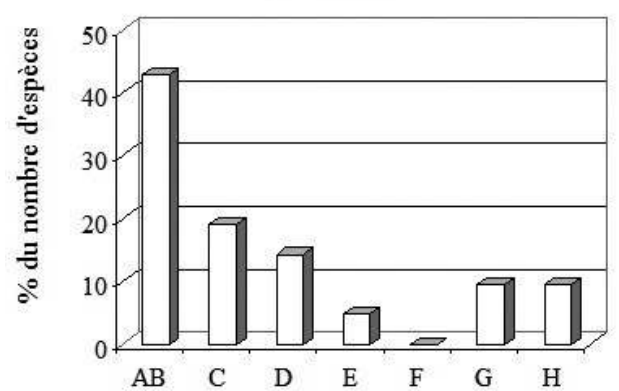

b/ Régime alimentaire

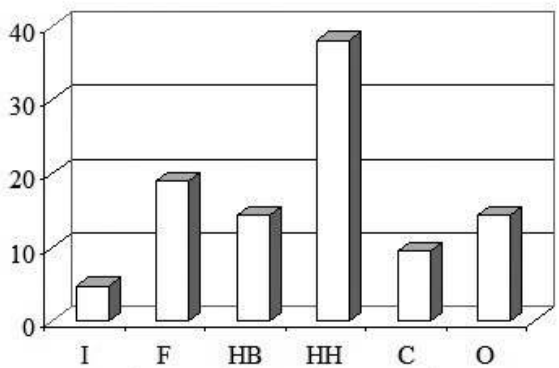

d/ Locomotion

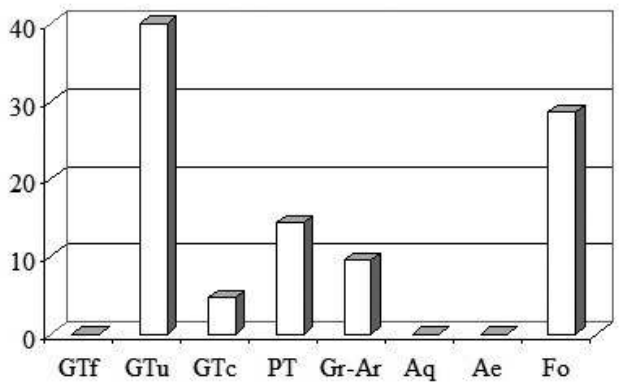




\section{2 - Cenogram} between the weight distribution of mammals and their environment. The cenogram method of J.A. Valverde (1964), as amended by S. Legendre, was to see graphically on the abscissa the different taxa, excluding carnivores, ranked in descending order of weight, and on the ordinate the logarithm of their mass in grams. The estimate of the average mass of most fossil species was done by S. Legendre according to the surface of the first lower molar according to a specific formula and to constants specific to the taxonomic groups (Legendre 1989). On the approximate weight of certain species other references were considered (table 2).

While species between $500 \mathrm{~g}$ and $5 \mathrm{~kg}$ are abundant in closed forest environment, they are absent or exceptional in the steppe open environment, resulting in a break of slope on the cenogram (fig. 5). Three taxa among the seventeen, excluding carnivores, identified at Hot Springs fall into this weight range, namely hares, rabbits and prairie dogs (appendix 2, fig. 6). Their presence suggests the existence of a mixed environment in which forest is not far behind. In addition, the more humid the context the more the ecological diversity is favoured, resulting in a smoother slope than in the case of a semi- desert environment (Legendre 1989). The slope is irregular in our case and the list of mammalian species rather limited so far. However, excessive aridity would likely have limited the presence of the very large species, which is not the case here.

Table 2 - Legend of cenogram from Hot Springs.

\begin{tabular}{|lrrrl|}
\hline Espèces & Rang & $\begin{array}{r}\text { Estimation } \\
\text { masse }(\mathrm{kg})\end{array}$ & $\begin{array}{r}\text { Log Y } \\
\text { (masse en g) }\end{array}$ & Référence \\
\hline Mammuthus colombi & 1 & 8000 & 15,8949 & Agenbroad, Mead 1994 \\
Mammuthus primigenius & 2 & 6000 & 15,6073 & Agenbroad, Mead 1994 \\
Arctodus simus & - & 600 & - & Figueirido et al. 2010 \\
Camelops hesternus & 3 & 570 & 13,25339 & actuelle Legendre 1989 \\
Hemiauchenia sp. & 4 & 92 & 11,43 & actuelle Legendre 1989 \\
Canis lupus & - & 45 & - & Legendre 1989 \\
Antilocapra americana & 5 & 39,6 & 10,587 & Legendre 1989 \\
Canis latrans & - & 13,4 & - & Legendre 1989 \\
Taxidea taxus & 6 & 6 & 8,68101 & Legendre 1989 \\
Lepus cf. townsendii & 7 & 1,5 & 7,313 & Legendre 1989 \\
Cynomys (Leucocrossuromys) sp. & 8 & 1,25 & 7,131 & actuelle \\
Mustela cf. vison/nigripes & - & 1 & - & Aulagnier al al. 2010 \\
Sylvilagus sp. & 9 & 0,95 & 6,86 & actuelle Legendre 1989 \\
Spermophilus cf. elegans/richardsonii & 10 & 0,32 & 5,75574 & Legendre 1989 \\
Neotoma cf. cinerea & 11 & 0,315 & 5,75257 & actuelle \\
Spermophilus cf. tridecemlineatus & 12 & 0,165 & 5,106 & Legendre 1989 \\
Thomomys talpoides & 13 & 0,105 & 4,654 & actuelle \\
Scalopus aquaticus & 14 & 0,058 & 4,06 & Legendre 1989 \\
Microtus sp. & 15 & 0,04 & 3,663 & actuelle Legendre 1989 \\
Phenacomys cf. intermedius & 16 & 0,035 & 3,5553 & actuelle \\
Peromyscus cf. maniculatus & 17 & 0,019 & 2,97 & Legendre 1989 \\
\hline
\end{tabular}

\section{3 - Palaeoenvironmental interpretation}

Ecological histograms and cenograms from Hot Springs tend to characterize an immediate mixed environment mixing steppe and forest under a generally sub-arid climate. Our results are consistent with all the palaeoenvironmental data that 
characterize a green island in the heart of the steppe (Mead et al. 1990). The pollen analysis thus indicates that $46 \%$ of pollens come from grasses (Poacea), although wetland plants of the sedge type (Carex), aquatic plants (Potamogeton, Polygonum), aromatic plants (Artemisia) or flowering plants (Ambrosia, Chenopodiaceae) are also found. As for the tree species, less abundant, the pollen analysis indicates the presence of spruce, followed by broad-leaved trees (birch, juniper, walnut, elm, oak).

Figure 5 - «Cénogrammes » interpretation, according to Montuire, Marcolini 2002.

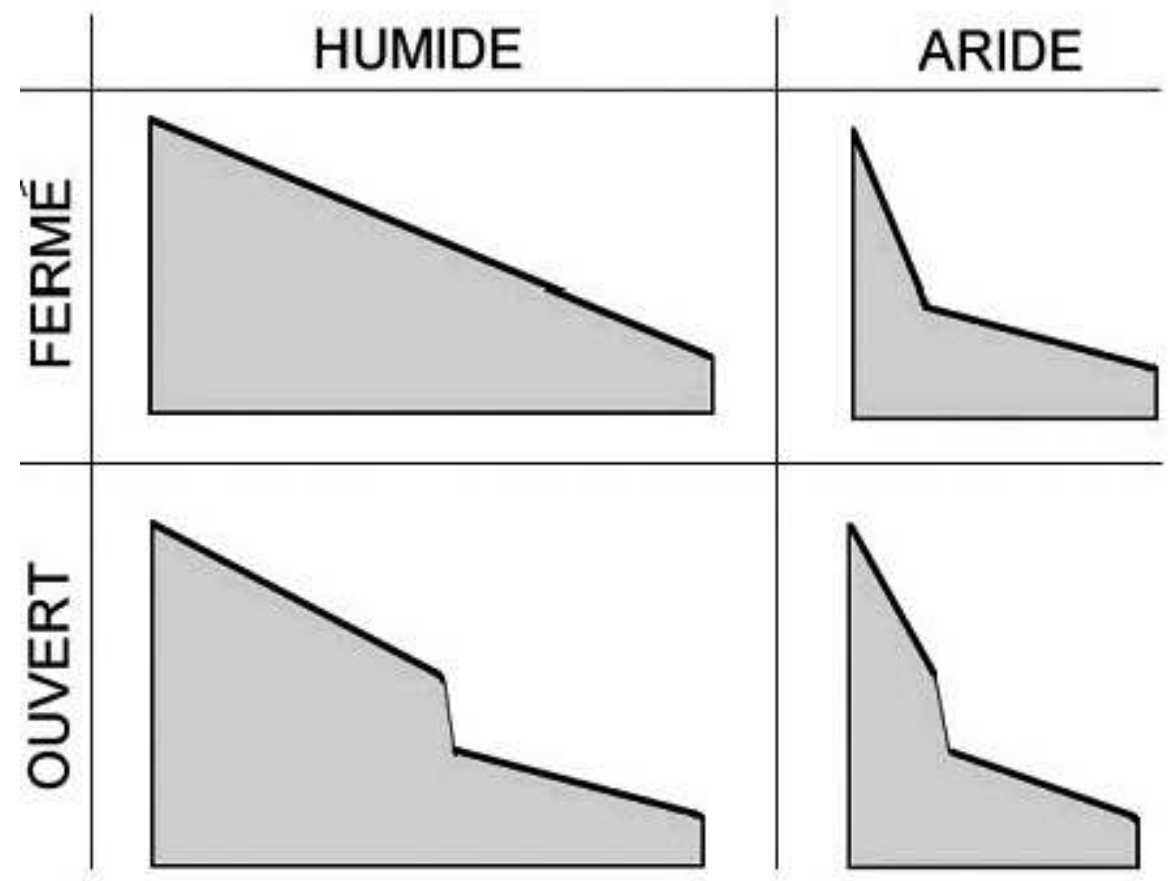

Figure 6 - « Cénogramme » from Hot Springs.

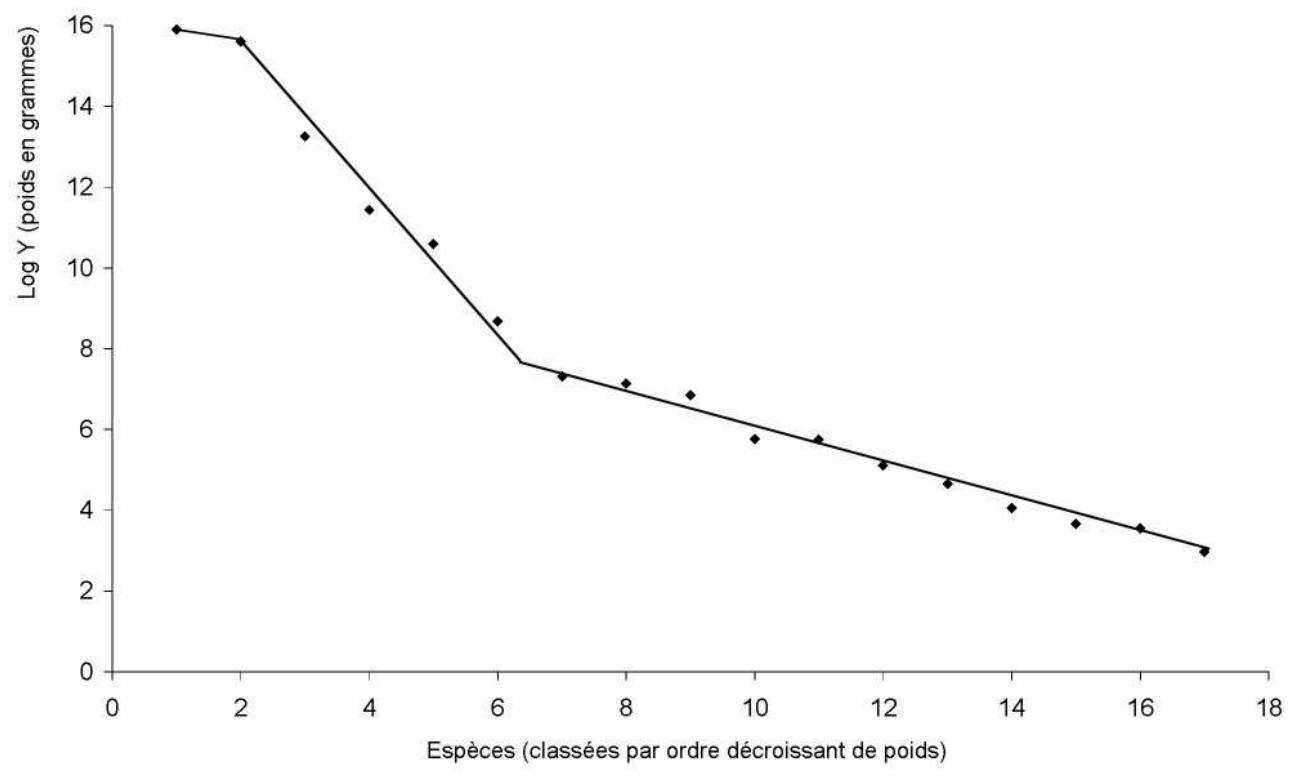




\section{4 - Review of the mortality profile of the mammoths: material and methods}

\section{1 - Overview of the cranial remains of the Columbian mammoths}

Among the skeletons of Mammuthus columbi with anatomical connections, the most complete is undoubtedly the one that has the number HS00140, its head having remained in close connection with the rest of the body (fig.7d). The 13S23W specimen, assigned by A. Lister to a female, has a near-complete in situ post -cranial skeleton. The 87-016 skull could be associated with it given its proximity and the distance between its occipital condyles (Lister in Agenbroad, Mead 1994).

Figure 7 - Mammuthus columbi cranial vestiges from Hot Springs.

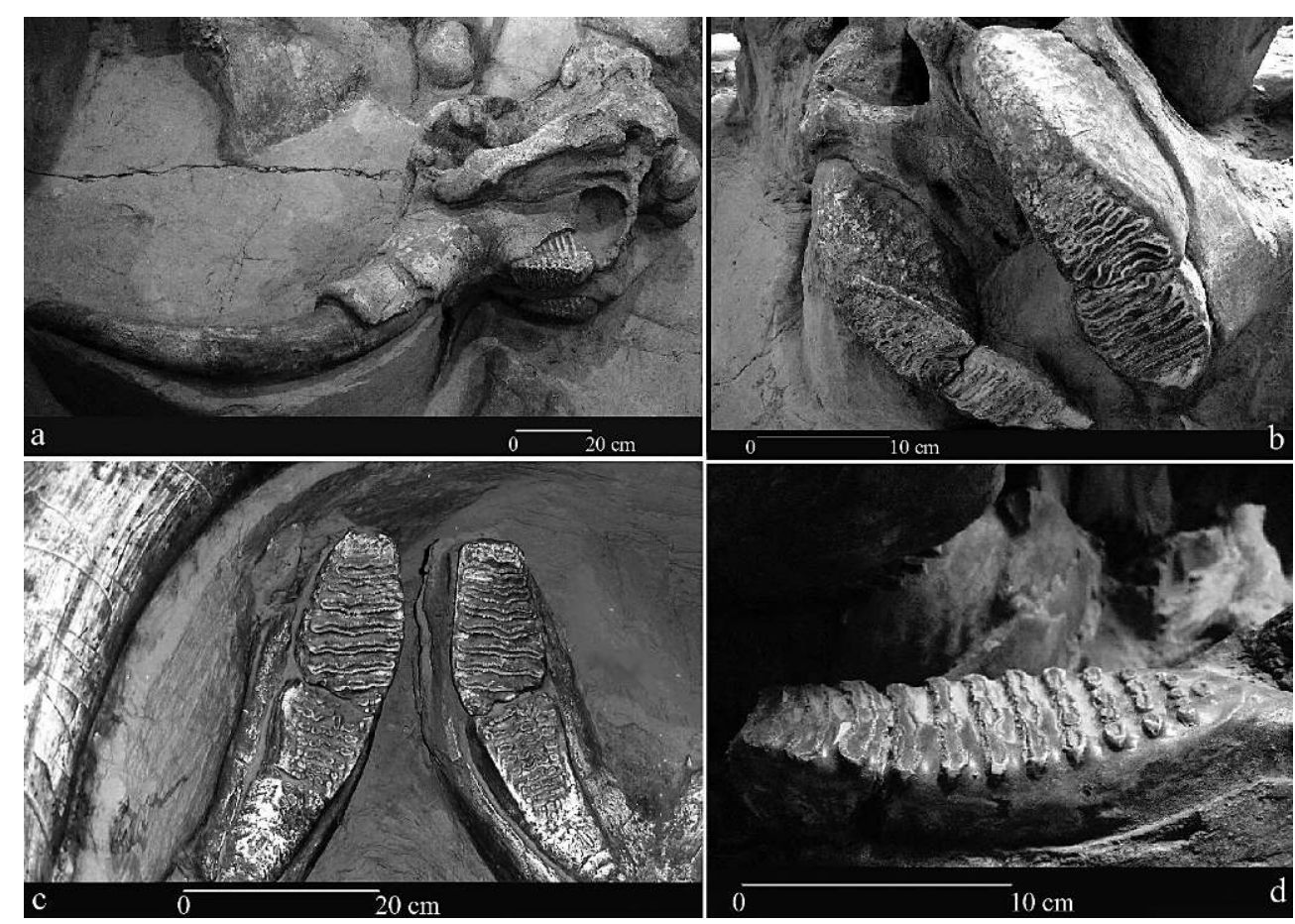

Among the twenty-three skulls studied by L.D. Agenbroad in 1994, nine did not allow the attribution of age, against one mandible out of the twelve taken in consideration at the time (Agenbroad, Mead 1994). Among the total of forty-eight jaws at the end of 2005 , seven did not allow us access to the molars. Only four skulls out of the twentyfour examined and three mandibles out of twenty-four once again did not give us access to the teeth (tab. 3 and 4 - Appendix). As many upper jaws as mandibles were thus taken into account without one knowing if it was possible or not to associate them. One hundred and eleven cheek teeth analyzed thus belong to dental series (two consecutive teeth, exceptionally three) against forty-six isolated molars, or a total of one hundred and fifty seven cheek teeth. Since late 2005, several postcranial elements have been exhumed. However, apart from the tusks, only one additional skull was unearthed during the excavation in 2009 (http://www.mammothsite.com).

Two difficult-to-access mandibles as well as twenty-five isolated dental remains are of indeterminate age. They are in thirteen cases fragments of molars consisting in a few lamellas and in six cases of single lamella. In the case of four whole molars partially 
concealed by the sediment, the uncertainty of the tooth row within the cheek teeth series can only give a possibility of origin (for example, M2 or M3). A tooth at the end of its life is finally so abraded than its origin is also questionable. Among the whole molars, it can be noted that one is around six to fifteen years old while the others are from individuals over twenty years old. We will put in perspective the importance to give to these undetermined isolated teeth. Indeed, it is likely that they are from jaws for which the age group was offered. Out of one hundred and fifty seven cheek teeth examined, in place or not in the jaw, no deciduous tooth is attested, however. The teeth are exclusively M1, M2 and M3 molars, and especially the last and penultimate molars (tab. 3 - in appendix).

\section{2 - Biometric study of the molars}

21 Let us recall that in Elephantidae dental renewal is quite special. Mammoth, like the elephant today, had in total twenty-four cheek teeth. Thus, per half-jaw, six cheek teeth succeeded each other during the life of the animal, that is to say three deciduals (D2, D3, D4 also called $\mathrm{m} 1, \mathrm{~m} 2$ and $\mathrm{m} 3$ by some authors) and three molars (M1, M2, M3). The replacement mode of the cheek teeth is quite original in Elephantidae because it happens in an "horizontal" manner actually following a very specific curvature. Thus, when a cheek tooth is substantially worn down by an abrasion phenomenon, it is pushed by the following and gradually disappears in favour of the latter, larger and at the beginning of its wear. Thus, there are never more than two functional teeth at a time on a half - jaw, maxillary or half-mandible. This sequence only comes to an end when the last permanent molar has also finished wearing down. Then the animals, unable to feed themselves, starve, approximately around 60 years old in current species (Laws 1966).

22 The work to which we mostly referred to determine the position of Mammuthus columbi cheek teeth in the dental series are those of H.F. Osborn (1942), J.J. Saunders (1970) and C.T. Madden (1981).

As the biometrics of the molar vary according to the degree of wear, it is imperative to consider the latter in order to put length, width or height measurements into perspective. In our study only measurements taken at a stage of wear allowing to keep the maximum dimensions of the tooth were retained (ideally wear stages A to C, fig. 8). By length (Li) of the tooth, we mean the length taken at the base of the tooth crown (Beden 1979). Other authors, such as V.J. Maglio (1973) or J.J. Saunders (1970) chose to measure the length (L) at mid-height of the tooth and perpendicular to the lamellas, and others parallel to the abrasion surface (in Agenbroad, Mead 1994 - p. 183). The synthesis of the measurements obtained on the molars of Mammuthus columbi at Hot Springs is shown in table 5.

We can note that the position of some of the jaws in the sediment has not allowed taking measurements of the molars. This is the case of four skulls and three mandibles of the "eastern part" and the "south-eastern part", all from adult individuals remained in situ on site (tabl. 4 - appendix). 
Table 5 - Synthesis of measurements obtained from cheek teeth of Mammuthus columbi, Hot Springs.

\begin{tabular}{|lrrrrrrrr|}
\cline { 2 - 9 } \multicolumn{1}{l|}{} & $\mathrm{N}$ & $\mathrm{Li}$ & $\mathrm{l}$ & $\mathrm{H}$ & $\mathrm{h}$ & $\mathrm{e}$ & $\mathrm{F}$ lat. F occl. \\
\hline Nombre de M2 supérieures & & & & & & & & \\
ayant permis la mesure & 5 & 2 & 17 & 2 & 2 & 21 & 7 & 21 \\
Moyenne & & & 82 & & & 2,2 & 7,4 & 7,3 \\
Mini & 13 & 200 & 70 & 122 & 167 & 1,4 & 7 & 6 \\
Maxi & 16 & 220 & 93 & 130 & 174 & 2,8 & 8,25 & 9 \\
écart type & & & 6,98 & & & 0,38 & 0,45 & 0,8 \\
Coefficient de variation & & & 8,51 & & & 17,37 & 6,13 & 10,97 \\
\hline Nombre de M2 inférieures ayant & & & & & & & & \\
permis la mesure & 4 & 2 & 13 & & & 16 & 1 & 16 \\
Moyenne & 14 & 204,5 & 75,8 & & & 2,4 & & 6,9 \\
Mini & 12 & 194 & 70 & & & 1,9 & 8,25 & 5,25 \\
Maxi & 15 & 215 & 89 & & & 3,4 & 8,25 & 8,5 \\
écart type & & & 5,44 & & & 0,4 & & 0,8 \\
Coefficient de variation & & & 7,18 & & & 16,67 & 11,55 \\
\hline Nombre de M3 supérieures & & & & & & & & \\
ayant permis la mesure & 3 & 3 & 13 & 9 & 9 & 11 & 11 & 9 \\
Moyenne & & 338,3 & 96 & 192,6 & 192,4 & 2,3 & 6,8 & 7 \\
Mini & 18 & 300 & 70 & 130 & 144 & 1,6 & 4,5 & 5,75 \\
Maxi & 23 & 375 & 108 & 223 & 223 & 3 & 8,5 & 8 \\
écart type & & 37,53 & 9,9 & 27,22 & 23,97 & 0,49 & 1,09 & 0,85 \\
Coefficient de variation & & 11,09 & 10,31 & 14,13 & 12,46 & 21,57 & 16,07 & 12,12 \\
\hline Nombre de M3 inférieures ayant & & & & & & & & \\
permis la mesure & 1 & 2 & 10 & 1 & 1 & 9 & 2 & 10 \\
Moyenne & & & 86,5 & & & 2,5 & & 7 \\
Mini & & 300 & 72 & 200 & 206 & 1,8 & 4,25 & 5,25 \\
Maxi & 23 & $>300$ & 100 & 200 & 206 & 3,3 & 6 & 8,5 \\
écart type & & & 8 & & & 0,46 & 1,15 \\
Coefficient de variation & & & 9,25 & & & 18,65 & 16,41 \\
\hline
\end{tabular}

Légende $: \mathrm{N}$ : nombre de lames, $\mathrm{Li}:$ longueur de la couronne dentaire (en mm), $1:$ largeur,

$\mathrm{H}$ : hauteur maximale, $\mathrm{h}$ : indice d'hypsodontie $\mathrm{h}=\mathrm{H} / \mathrm{l} \times 100$, e : épaisseur d'émail,

$\mathrm{F}$ : fréquence laminaire (nombre de lames sur $10 \mathrm{~cm}$ ), mesure latérale et occlusale.

\section{3 - Assigning individual ages}

A molar, even if it is not whole, provides a number of very useful information, such as the species to which the animal belongs but also the age at death. Thus, the study of tooth wear of each cheek tooth tells us about the age at death of the individuals. This analysis is therefore the preliminary step to the establishment of mortality curves.

Elephantidae cheek teeth consist of a series of more or less large transverse lamellas held together by the cement. These lamellas are themselves formed by a thin fold of ivory covered with a thicker enamel layer. The lamellas wear down nearly perpendicularly during abrasion, thus their size decreases progressively, leading therefore to reduce the height of the tooth. Several methods were proposed in order to assess the degree of wear of the Elephantidae cheek teeth. Among them, we will mention the $\mathrm{Nf} / \mathrm{N}$ ratio frequently used (number of lamellas opened / total number of lamellas). However, if this formula is more than convincing regarding the whole molars, it is not applicable to dental pieces.

Knowledge of the tooth wear stage is a very important parameter because the only position of the molar in the cheek teeth series is not sufficient to assign an age to the animal, or else it would be too approximate, especially for the last molars.

We have opted for R. M. Laws' classification of wear stages (1966) obtained on current elephants, coupled with the method for which M. Beden (1979) created a theoretical model applicable to "definitive" lower molars and we similarly established the one applicable to upper molars (fig. 8). To do this, almost two hundred mammoth upper cheek teeth from the site of Hanhoffen in the Bas-Rhin, Germany, were thoroughly 
analyzed (Louguet-Lefebvre 2005, 2006). The stages of wear thus defined by M. Beden range from new tooth (stage A) to end of life tooth, abraded at $100 \%$ (stage D4), passing through the stages of progressive destruction of the lamellas (stages D1 to D3 included). This method, like that of R.M. Laws, takes into account both the relative amount of lamellas in use and the estimation of missing lamellas due to wear, but it also takes into account the angle of the abrasion table with the dental crown. This last parameter is especially useful in the case of incomplete molars. That is why the correlation between this method and R.M. Laws' is interesting. It allows assigning a relatively precise age group to tooth fragments, including upper ones (table 6).

Table 6 - Attribution of main age groups to Elephantids.

\begin{tabular}{|c|c|c|c|}
\hline \multicolumn{2}{|c|}{ R. M. Laws (1966) } & \multicolumn{2}{|c|}{ M. Beden (1979), S. Louguet-Lefebvre (2005) } \\
\hline Age (en années) & Stade d'usure dentaire & Type de dent & Stades d'usure dentaire \\
\hline \multirow{3}{*}{ jusqu'à 2} & \multirow{3}{*}{ I à IV } & D2 & Tous \\
\hline & & D3 & $\mathrm{A}$ à $\mathrm{C}$ \\
\hline & & D4 & $\mathrm{A}$ à B2 \\
\hline \multirow{3}{*}{3 à 4} & \multirow{3}{*}{ V à VII } & D3 & $\mathrm{D}$ \\
\hline & & D4 & $\mathrm{B} 3$ à $\mathrm{C}$ \\
\hline & & M1 & $\mathrm{A}$ \\
\hline \multirow[t]{2}{*}{6 à $10(+/-1)$} & \multirow[t]{2}{*}{ VII à IX } & D4 & $\mathrm{C}$ à D3 \\
\hline & & M1 & $\mathrm{B} 1$ à $\mathrm{B} 3$ \\
\hline \multirow{3}{*}{13 à $20(+/-2)$} & \multirow{3}{*}{ X à XIII } & D4 & D3 à D4 \\
\hline & & M1 & B4 à D2 \\
\hline & & M2 & A à B2 \\
\hline \multirow{3}{*}{22 à $34(+/-2)$} & \multirow{3}{*}{ XIV à XX } & M1 & D3 à D4 \\
\hline & & M2 & B3 à D2 \\
\hline & & M3 & A à B2 \\
\hline \multirow[t]{2}{*}{36 à $47(+/-2)$} & \multirow[t]{2}{*}{ XXI à XXV } & M2 & D3 à D4 \\
\hline & & M3 & $\mathrm{B} 3$ à $\mathrm{C}$ \\
\hline 49 à $62(+/-2)$ & XXVI à XXX & M3 & $\mathrm{D}$ \\
\hline
\end{tabular}

The small existing differences between the ages assigned by different authors may impact the mortality profile, which is why it is crucial to note to which methodology we refer to. For example, the

XVl class defined by R.M. Laws was attributed to an age close to 26 years old, thereafter G.C. Craig matched it an approximate age of 19 to 21 years old (Craig in Haynes 1991). This is perhaps what partly explains the differences observed between the mortality profiles of Hot Springs established by different authors, even if the constant growth of the studied sample remains an undeniable profile modification factor. The estimation of age that we propose here is based on the model established by R.M. Laws on African elephants (1966), as current elephant have a dental formula similar to that of the mammoth and a life expectancy supposedly close.

The most complete specimen (HS00140) had the advantage of having its two jaws. The analysis of the mandible and of the maxilla enabled us to assign to the individual an approximate age that should be around 40 to 45 years. Its last lower molars have nearly three quarters of open enamel lamellas and no lamella disappeared through wear, that 
is to say a B4 stage wear corresponding to the morphological stage XXIII defined by R. M. Laws.

\section{5 - Results: development of a new mortality profile}

\section{1 - Contribution of previous studies}

Several authors have previously studied the molars of Mammuthus columbi from Hot Springs in order to develop a mortality profile at a $\mathrm{T}$ instant of the excavation. Thus $\mathrm{B}$. Dutrow in 1980 studied the forty-six cheek teeth excavated at that time and determined a MNI (minimal number of individuals) of eight (Dutrow 1980). In 1987, L.D. Agenbroad and J. Mead determined from the molars no less than twenty- six individuals (Agenbroad, Mead 1987) and forty-three from the count of the tusks carried out in 1990, and that for only twelve humerus (Agenbroad 1990). The study of the eighty molars then allowed L.D. Agenbroad to conduct the revision of nearly half of the ages that were previously determined by B. Dutrow and to establish a new mortality profile, while the MNI was then estimated to fifty-nine individuals (Dutrow in Agenbroad, Mead 1994). However, this is a frequency MNI and not the combination MNI we are referring to. Insofar as isolated teeth are considered, resorting only to MNI frequency has the disadvantage of significantly overestimating the number of individuals less than 40 years old. Indeed, these individuals have two teeth in use on each half- jaw against a single last molar beyond this age (M3). If we consider for example two isolated upper left teeth, more precisely an M1 with a wear stage $C$ and M2 having reached the A wear stage, it is possible that these two teeth are issued from the same individual. The resulting profile then presented a clear overrepresentation of individuals aged 10-19 years and 20-29 years, as these age groups concentrated $80 \%$ of the data, the remaining $20 \%$ being divided almost equally between the last three age groups. All authors agree in any case on the fact that no mammoth young was unearthed at Hot Springs, as evidenced by the absence of deciduous molars. Judging by the count of the tusks made to date by the L.D. Agenbroad foundation, the number of Columbian mammoths could reach fifty seven individuals in 2012 (http://www.mammothsite.com).

Figure 8 - Attrition levels of Elephantid cheek teeth, according to M. Beden, 1979 (lower teeth) and S. Louguet-Lefebvre, 2005 (upper teeth).

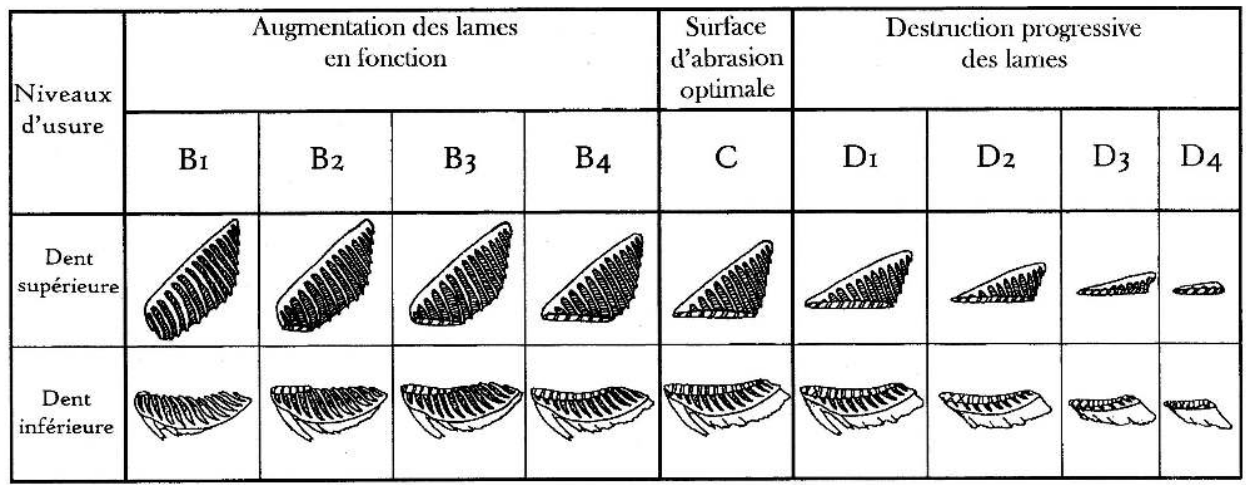




\section{2 - Review of the mortality profile}

The ages allocated to ten skulls by A. Lister by using the measurements provided by the occipital condyles (Lister in Agenbroad, Mead 1994) corroborate the ages we obtained on these skulls by studying their cheek teeth. Moreover, our analysis allows clarifying the results from the osteological studies carried out by L.D. Agenbroad (1990) which indicated an overrepresentation of males aged between 10 and 35 years.

To determine the MNI (minimal number of individuals), we obviously took into consideration the possibility that an upper jaw (or two maxillaries), a mandible (or two hemi- mandibles) and one or more isolated teeth could come from a single individual. To date, only the HS00140 specimen has both jaws, also clearly associated by anatomical connection with the rest of the post -cranial skeleton, although other maxillary - mandible associations are possible. To determine the MNI we first added the maximum number of teeth of the same type (M3, M2), in strictly identical positions (upper or lower, left or right) and with an almost identical degree of wear by accepting a margin of evaluation in a stage (i.e. B4 for a tooth and C for another). We then divided our MNI by age category referring to table 6 . The combination MNI then consisted of the addition of the respective MNI of each age category, that is to say thirty-three to which we added three, as three non accessible mandibles because of their position in the sediment come from individuals of unknown age (table 7). This calculation allowed us to review the latest estimates downward, since the cheek teeth come from a minimum of thirty- six individuals. This minimal number is without common measure with that provided up to date by the tusks, which could reach fifty seven. The excavations in the coming decades should help to gradually diminish this gap.

Our review of the mortality profile of Mammuthus columbi, in light of recent data, indicates that the trap has affected a majority of adult subjects, since twenty-two individuals out of a total of thirty-six identified by their molars died at an approximate age between 25 and 38 years (table 7, fig . 9). The absence of deciduous teeth, as well as the lack of M1, not or slightly worn, confirms the absence of very young individuals and juveniles under the age of 10 . The deficit in senile individuals associated with the lack of very young mammoths is surprising. 
Table 7 - Mammuthus columbi from Hot Springs in MNIc.

\begin{tabular}{|cc|}
\hline Classes d'âge (en années) & NMI c \\
\hline $0-12$ & 0 \\
$13-24$ & 4 \\
$25-38$ & 22 \\
$39-47$ & 3 \\
$>47$ & 4 \\
Total (d'âge connu) & 33 \\
Âge non connu & 3 \\
\hline TOTAL & 36 \\
\hline
\end{tabular}

Figure 9 - Mortality profile of the Mammuthus columbi from Hot Springs, South Dakota (MNIc according to cheek teeth : 36 ).

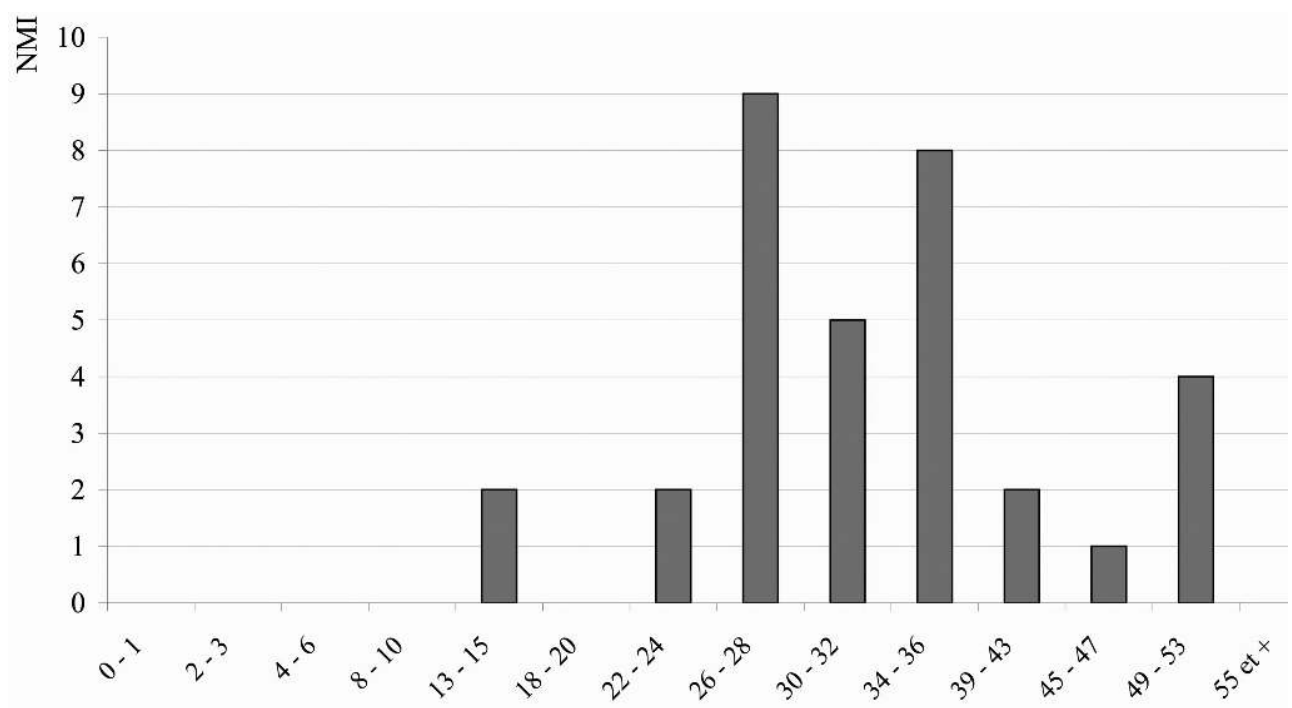

âge approximatif (en années)

\section{6 - Discussion}

\section{1 - Characterization of the different mortality profiles}

Mammoths, like elephants, must have been gregarious animals. Among current elephants, the herd, led by a matriarch, can include up to thirty individuals from the same family, mostly females with their young, young and old males. Males having 
reached sexual maturity for two or three years are excluded for their herd and adopt a solitary life, but eventually gather between them, returning to the females only for procreation (Laws 1966). possible to draw a parallel between the profile obtained in Hot Springs and the assessment of the proportion of males he drew from populations of Loxodonta males from different National Parks in north-western Zimbabwe (personal communications 2005 and 2008, Haynes 1991). Although his estimate of ages is done approximately, it is clear from numerous observations that there is a neat overrepresentation, in males, of elephants in the prime of age. The 13-36 year-old total well over half of the individuals, followed to a lesser extent by the under 37 years old accompanied by an absence of 
individuals under 12 years of age. These estimates in proportions of male elephants put forward by Gary Haynes only take into account here the males that were not integrated into mixed herds. They may underestimate some individuals of more than 37 years if we consider that adult males of approximately 37 to 48 years can be temporarily associated with the mixed herds even of they remain primarily composed of females and young (Haynes 1991).

The overrepresentation of adult mammoths between 25-38 years, nearly two out of three in the case of Hot Springs, the low proportion of other age groups and the absence of individuals under 12 years old are as many common points between Hot Springs and the sites mentioned above. The interpretation of this mortality profile is difficult to establish, especially as such a configuration is not sufficiently documented at the moment, as we just mentioned. However, the strong similarities observed between the profile of Hot Springs and the proportions of males observed in Zimbabwe would tend to compare this profile with the type $C$ defined by Gary Haynes, resulting notably from selective mortality that affected only males, except that in both cases subadults are absent

Except the site of Hot Springs, which is an exception, most deposits with high bone accumulation of Elephantidae (fossil or modern) usually result mainly from mixed herds containing at the most several adult males (Haynes 1991).

\section{3 - The trap would occasionally have affected males and mixed herds}

If we look at the Asian elephants, Elephantidae are excellent swimmers and the adults do not hesitate in putting themselves in danger to help their descendants. It could be imagined that the adult females at Hot Springs could have rescued their young, carefree and vulnerable, by helping them to get out of the water. The fact that there is no young does not necessarily mean that the trap affected only isolated males; it may also include members from groups of females out of which the youngest, less heavy, could have escaped.

This hypothesis could possibly be supported by the overrepresentation, in number of remains as well as in MNI, of pachyderms about five to ten tons at the expense of smaller mammals (giant short-faced bear of nearly $600 \mathrm{~kg}$, camels, llamas, pronghorn antelopes, wolves, coyotes, badgers - Agenbroad, Mead 1994) and of young mammoths still far from their maximum weight. Indeed, if we judge by present-day elephants, the weight of the young mammoth at birth should have been close to $100 \mathrm{~kg}$, and then gradually increased at a rate of a kilo per day, reaching an adult weight of around eight tons. Thus, it appears that Elephantidae trapped in Hot Springs would not weigh less than 4.5 tons.

The isotopic oxygen study carried out by D.C. Fisher on samples of tusks from Hot Springs seems to indicate an annual "bimodal" distribution of mortality. The trap could have worked especially in spring and autumn (Fisher et al. 2003). The distribution of mortality could thus be explained by the particularly unstable soaked banks in both seasons, while the dry soil in summer and the frozen one in winter would have facilitated the ascent of elephants by more stable banks that did not give way under their colossal weight. 
Finally, even if too few bone elements have allowed to establish the sex ratio of the population, females are not excluded from this accumulation as evidenced by one of the most beautiful specimens in connection in situ (postcranial skeleton 13S23W) assigned by A. Lister to a female (Lister in Agenbroad, Mead 1994). This calls into question the previously mentioned hypothesis that evokes a possible lack of family groups in the composition of the bone assemblage of proboscidea.

\section{7 - Conclusion}

The contribution of the analysis of the Hot Springs Elephantidae cannot be overlooked because it completes unexpectedly the existing natural mortality referential. However, it is difficult to interpret accurately the resulting mortality profile of Mammuthus columbi. Indeed, a significant over-representation of adults and the absence of young animals are evidenced out of a minimum of thirty- six individuals, taking into account the analysis of the molars. This type of configuration has only few equivalents and remains insufficiently documented at present. Therefore, no interpretation is preferred. The trap could have affected occasionally isolated males, small groups of males, or mixed herds out of which the younger, less heavy, could have extracted themselves with the help of the adults. Conversely, it is possible that unstable banks collapsed under the weight of huge adult pachyderms, leaving them little chance to get out of this mess which then offered no more hold in case of fall, otherwise said no escape.The summer excavations led by L.D. Agenbroad and his team could help to update the MNI with the latest findings and to clarify the mortality profile within a few years.

\section{BIBLIOGRAPHY}

AGENBROAD L.D. 1989 - Spiral Fractured Mammoth Bone from Nonhuman Taphonomic Processes at Hot Spring Mammoth Site. In : R. Bonnichsen, M.A. Sorg (Eds.), Bone Modification. Orono: Center for the Study of the First Americans, University of Maine, p. 139-147.

AGENBROAD L.D. 1990 - The mammoth population of the Hot Springs site and associated megafauna. In : L.D. Agenbroad, J. I. Mead, L. Nelson (Eds.), Megafauna and Man. The discovery of America's Heartland. Hot Springs, South Dakota: Mammoth Site of Hot Springs, p. 32-35.

AGENBROAD L.D., MEAD J.I. 1987 - Age structure analysis of Mammuthus columbi, Hot Springs, South Dakota, Current Research in the Pleistocene 4, p. 101-102.

AGENBROAD L.D., MEAD J.I. 1994 (Eds.) - The Hot Springs Mammoth Site: a Decade of Field and Laboratory Research in Paleontology, Geology, and Paleoecology, Mammoth Site of Hot Springs. South Dakota, Inc., Hot Springs. 451 p.

ANDREWS P., LORD J.M., NESBIT-EVANS E.M. 1979 - Patterns of ecological diversity in fossil and mammalian faunas. Biology journal Linnean Society, 11, p.177-205. 
AULAGNIER S., HAFFNER P., MITCHELL-JONES T., MOUTOU F., ZIMA J. 2010 - Guide des mammiferes d'Europe, d'Afrique du Nord et du Moyen-Orient. Paris, Ed. Delachaux et Niestlé. 272p.

BEDEN M. 1979 - Les Éléphants d'Afrique Orientale : systématique, phylogénie, intérêt biochronologique. Thèse de la Faculté des Sciences Universitaires de Poitiers, 2 vol., 567 p. (inédit).

CRAIG G.C. 1991 - in: Haynes G. 1991 - Mammoths, mastodonts and elephants. Biology, behavior, and the fossil record. Cambridge University Press, $413 \mathrm{p}$.

DUTROW B. 1980 - Metric analysis of a Late Pleistocene Mammoth Assemblage, Hot Springs, South Dakota. M.S. thesis, Southern Methodist University (unpublished).

FIGUEIRIDO B., PÉREZ-CLAROS J. A., TORREGROSA V., MARTÍN-SERRA A., PALMQVIST P. 2010 Demythologizing Arctodus simus, the " Short-Faced " long-legged and predaceous bear that never was, Journal of Vertebrate Paleontology, 30: 1, p. 262-275.

FISHER D.C, FOX D.L., AGENBROAD L.D. 2003 - Tusk growth rate and season of death of Mammuthus columbi from Hot Springs. South Dakota, USA Deinsea, 9, p. 117-133.

FLEMING T.H. 1973 - Numbers of mammal species in north and central America forest communities. Ecology, 54, n 3, p. 555-563.

GUÉRIN C., FAURE M. 1987 - Grands Mammifères. In :J.C. Miskovsky et al., Géologie de la Préhistoire : méthodes, techniques, applications, Géopré édit., Maison de la Géologie, Paris, p. 801-830.

HANNUS L.A. 1989 - Flaked Mammoth Bone from the Lange Ferguson Site, With River Badlands Area, South Dakota. In : R. Bonnichsen, M.A. Sorg (Eds.), Bone Modification. Orono: Center for the Study of the First Americans, University of Maine, p. 395-412.

HAYNES G., 1987 : Proboscidean die-offs and die-outs : Age profiles in fossil collections. Journal of Archaeological Sciences. 14(6) : p. 659-668.

HAYNES G. 1991 - Mammoths, mastodonts and elephants. Biology, behavior, and the fossil record. Cambridge University Press, $413 \mathrm{p}$.

LAURY R.L. 1990 - Geologic History of the Mammoth site and Surrounding Region Hot Springs Area, Fall River and Custer Counties, South Dakota: An Overview. In : L.D. Agenbroad, J.I. Mead, L.W. Nelson (Eds.), Megafauna and Man. Flagstaff, Arizona, p. 15-21.

LAWS R.M. 1966 - Age criteria for the African elephant, Loxodonta a. africana. East African Wildlife Journal. 4, p. 1-37.

LEGENDRE S. 1989 - Les communautés de mammifères du Paléogène (Éocène supérieur et Oligocène) d'Europe occidentale : structures, milieux et évolution. Ed. F. Pfeil., München 265 p.

LOUGUET-LEFEBVRE S. 2005 - Les mégaherbivores au Paléolithique moyen en Europe du Nord-Ouest : paléoécologie, taphonomie et aspects palethnographiques. British Archaeologial Reports, International Series / S1451, $357 \mathrm{p}$.

LOUGUET-LEFEBVRE S. 2006 - Determining the age of death of Proboscids and Rhinocerids from dental attrition. Oxbow, Icaz Durham 2002, International Council of Archaeozoology, 9th Conference, 23-28 August, p. 179-188.

MADDEN C.T. 1981 - Mammoths of North America. Ph. D. thesis of Colorado University, Ann Arbor, 271 p. (unpublished).

MAGLIO V.J. 1973 - The origin and evolution of the Elephantidae. The American Philosophical Society, $62,149 \mathrm{p}$ 
MEAD J., HELVY R.H., AGENBROAD L.D., 1990 - Late Pleistocene Invertebrates and Plant Remains, Mammoth Site, Black Hills, South Dakota. In : L.D. Agenbroad, J.L. Mead, L. Nelson (Eds.),

Megafauna and Man. The discovery of America's Heartland. Hot Springs, South Dakota: Mammoth Site of Hot Springs, p. 9.

MONTUIRE S., MARCOLINI F. 2002 - Palaeoenvironmental significance of the mammalian faunas of Italy since the Pliocene. Journal of Quaternary Science, vol. 17(1), p. 87-96.

OSBORN H.F. 1942 - Proboscidea, a Monograph of the Diversity, Evolution, Migration and Extinction of the Mastodons and Elephants of the World, Vol. II: Stegodontoidea, Elephantoidea. American Museum of Natural History, New York, p. 805-1675.

PÉAN, S. 2001 - Comportements de subsistance au Gravettien en Europe centrale. Thèse Doct. MNHN Paris. 413 p. (unpublished).

SAUNDERS J.J. 1970 - The distribution and taxonomy of Mammuthus in Arizona. M.Sc. thesis of Arizona University, Tucson, 115 p. (unpublished).

STANFORD D., WEDEL W. R., SCOTT G. R. 1981 - Archaeological investigations of the Lamb Spring site. Southwestern Lore 47(1), p. 14-27.

VALVERDE J.A. 1964 - Remarque sur la structure et l'évolution des communautés de vertébrés terrestres. Terre et Vie, III, p. 121-154.

\section{APPENDIXES}


Table 3 - Mammuthus columbi check teeth data, Hot Springs.

\begin{tabular}{|c|c|c|c|c|c|c|c|c|c|c|c|c|c|c|c|}
\hline$N^{\circ}$ pictec & Photo Position dent & $\mathrm{N}$ & $\mathrm{Nd}$ & $\mathrm{Nf}$ & $\mathrm{Li}$ & 1 & $\mathrm{H}$ & h & u & & F lat. & F oecl. & Laws & Age approx & Remarques \\
\hline \multirow[t]{4}{*}{78.157} & M2 sup. d. & 9 & $\propto 9(\infty)$ & 9 & & (77) & & & D2 & 2,3 & & 6 & $\mathrm{XX}$ & & \\
\hline & M3̂ sup. d. & $>18$ & (ळ) $18-$ & 5 & 340 & 90 & (130) & 144 & B2 & 2,5 & 7 & 7 & & & \\
\hline & M2 sup. $g$. & 7 & $\propto 7(\infty)$ & 7 & & (80) & & & D2 & 2,3 & & 6 & & & \\
\hline & Mà sup. g. & $>18$ & (ळ) $18-$ & 5 & 330 & 90 & & & B2 & 2,5 & 7 & 7 & & & \\
\hline \multirow[t]{4}{*}{ MSL1172 } & M2 inf. g. & 14 & -14 & 12 & & 87 & & & c & 3,2 & & 5,5 & XVI-XVII & $25-38$ & Cément important \\
\hline & M3 inf. g. & $?$ & $?$ & 0 & & & & & A & & 4,25 & & & & \\
\hline & $\mathrm{M} 2$ inf. $\mathrm{d}$. & 10 & -10 & 9 & & 89 & & & c & 3,2 & & 4,75 & & & \\
\hline & M3 inf. d. & $?$ & $?$ & 0 & & & & & A & & 4,25 & & & & \\
\hline \multirow[t]{2}{*}{ Sans $\mathrm{N}^{*} 9$} & M2 inf. g. & 13 & -13 & 12 & & 72 & & & c & 2,4 & & 7 & XVI-XVII & $25-38$ & \\
\hline & M3 inf. g. & $?$ & $?$ & 0 & & 97 & & & A & & & & & & \\
\hline \multirow[t]{2}{*}{ Sans $\mathrm{N}^{2} 10$} & M3 inf. d. & $\$ 17$ & $\propto 17+$ & 13 & (290) & 97 & & & B4 & 2,9 & & 5.5 & XXIII & $39-47$ & \\
\hline & M3 inf g. & 317 & $\propto 17+$ & 13 & (290) & 100 & & & $\mathrm{~B}^{\mathrm{B}}$ & 2,9 & & 5,5 & & & \\
\hline \multirow[t]{4}{*}{$87.523 / \div 108$} & M2 inf. g. & 6 & $\infty 6(\infty)$ & 6 & & & & & D3 & & & & $\mathrm{XXI}$ & $25-38$ & Cément des M33 important \\
\hline & $\begin{array}{l}M 3 \text { inf, } g . \\
M 2 \text { inf }\end{array}$ & ${ }_{6}^{22}$ & $\begin{array}{lll}(\infty) 222 & 22 \\
\infty & 6(x)\end{array}$ & 8 & $(300)$ & 80 & & & $\begin{array}{l}\mathrm{B}^{\mathrm{B} 3} \\
\mathrm{D} 3 \mathrm{~B}\end{array}$ & $\begin{array}{l}3,3 \\
3,4\end{array}$ & & 7,5 & & & \\
\hline & M2 inf. d. & & & ${ }_{9}^{6}$ & $(300)$ & & & & B3 & & & & & & \\
\hline & M3 inf. d. & & $(\infty) 22$. & & & & & & & 3,3 & & 7,5 & & & \\
\hline \multirow[t]{4}{*}{ Sans $\mathrm{N}^{2} 11$} & M2 inf. d. & 10 & $\propto 10$ & 10 & (203) & 73 & & & D1 & 2,5 & & 6 & XVIII & $25-38$ & Cément des M2 important \\
\hline & M2 inf. g. & 10 & $\propto 10$ & 10 & & 76 & & & D1 & 2,5 & & 6 & & & \\
\hline & M3 inf. d. & $?$ & $?$ & 0 & & & & & $\mathrm{~A}$ & & & & & & \\
\hline & M3 inf. g. & ? & $?$ & 0 & & & & & A & & & & & & \\
\hline \multirow[t]{2}{*}{ MSL 744 / 85.002} & M2 sup. g. & 13 & $-13 x$ & 13 & & 79 & & & c & 2,8 & & 7,5 & XVI-XVII & $25-38$ & Cément de la M2 important \\
\hline & M3 sup. g. & 4 & $4-$ & 0 & & & & & $\mathrm{~A}$ & & & & & & \\
\hline \multirow[t]{3}{*}{ HS00035 / MSL937 } & M1 inf. d. & 2 & $\infty 2(\infty)$ & 2 & & (70) & & & D4 & & & & $\mathrm{XVI}$ & $25-38$ & Cément des M2 important \\
\hline & M2 inf. d. & $12 ?$ & (ळ) $12 ? \mathrm{x}$ & 11 & & 70 & & & B4 & 2,4 & & 8 & & & \\
\hline & M2 inf, g. & $13 ?$ & (œ) $13 ? \mathrm{x}$ & 13 & (194) & 72 & & & B4 & 2,4 & & 7,75 & & & \\
\hline \multirow[t]{2}{*}{ Sans $\mathrm{N}^{*} 12$} & M2 inf. d. & 12 & $12 \times$ & 12 & & 74 & & & c & 1,86 & & 6,75 & XVI-XVII & $25-38$ & \\
\hline & M3 inf & $?$ & $?$ & 0 & & & & & $\mathrm{~A}$ & & & & & & \\
\hline \multirow{3}{*}{ " Manfred" } & M2 sup. d. & 13 & $\infty 13 x$ & 12 & (206) & 80 & & & $c$ & 2,4 & & 7,25 & $\mathrm{XVI} \cdot \mathrm{xVII}$ & $25-38$ & \\
\hline & M2 sup. g. & 13 & $\infty .13 x$ & 12 & (213) & 84 & & & c & 2,4 & & 7 & & & \\
\hline & M3 sup. g. & ? & $?$ & & & & & & & & & & & & \\
\hline Sans $N^{*} 13$ & M2 inf. d. & 13 & is $13(x)$ & 13 & & 76 & & & D1 & 2,3 & & 6.5 & xVIII & $25-38$ & \\
\hline HSO0297 & M sup. d. & 5 & & 0 & & (72) & (178) & 247 & $?$ & $?$ & 7 & & $?$ & $?$ & \\
\hline Sans $\mathrm{N}^{*} 14$ & M2/3 sup. & $>11$ & «111? & 11 & & $(\mathrm{~N} 2)$ & & & D & 2,6 & 7 & & & & Encore enfouie dans le sédiment \\
\hline HSO0206 & M sup. g. & $>6$ & $6+$ & 6t & & (77) & & & $?$ & $?$ & & 7 & $?$ & ? & Coincée entre maxillaire et sédiment \\
\hline 05 IIS105 & M sup.? & 3 & $\times 3-$ & 0 & & (75) & $(158)$ & 211 & $\mathrm{~A}$ & & & & $?$ & $?$ & \\
\hline IIS00706? & M2 sup. d. & 13 & 13 & 13 & & 80 & & & $\mathrm{c}$ & 2,6 & & 7,5 & $\mathrm{xVII}$ & $25-38$ & Seule en place dans le maxillaire \\
\hline Sans $\mathrm{N}^{\mathrm{O}}$ & M3 su & 14 & & 6 & (230) & $(102-)$ & 190 & $186+$ & B2 & 1,88 & 6,5 & 8 & $x x$ & $25-$ & \\
\hline & & $\$ 11$ & $\approx 11+$ & 11 & & 80 & & & D1 & 2,6 & & 6 & xVIIII & $25-38$ & Seule en place dans le maxillaire \\
\hline 90115102 & M2/3 sup.? & 9 & $\infty 9$ & 9 & & (70) & & & D3 & 2,2 & & $?$ & $?$ & $?$ & En partie masquée par le sédiment \\
\hline Sans $\mathrm{N}^{\prime \prime} 15$ & $\mathrm{M} 2 / 3 \mathrm{inf} . \mathrm{g}$. & $>11$ & $11+$ & $11+$ & & & & & 134 & 2,8 & & 6 & & & Ilémi-mandibule sortant du sédiment \\
\hline Sans $\mathrm{N}^{\prime} 16$ & M3 inf, d. & 10 & $\infty 10$ & 10) & & 84 & & & DI & 2,3 & & 6,5 & xxvi & $>47$ & Dans l'hémi-mandibule. Cément + \\
\hline
\end{tabular}

\begin{tabular}{|c|c|c|c|c|c|c|c|c|c|c|c|c|c|c|c|}
\hline$N^{0}$ pièce & Photo Position dent & $\mathrm{N}$ & $\mathrm{Nd}$ & $\mathrm{Nf}$ & $\mathrm{Li}$ & 1 & $\mathrm{H}$ & $\mathrm{h}$ & $\mathrm{u}$ & $\mathrm{e}$ & $\mathrm{F}$ lat. & F occl. & Laws & & Remarques \\
\hline Sans $\mathrm{N}^{\circ} 17$ & M3 sup. & $?$ & $?$ & $?$ & & & & & $?$ & & & & & & Accessibilitíe gênée dans le maxillaire \\
\hline MSL692 & M2 sup. g. & 15 & $-15 x$ & $11-$ & & & & & c & 1,8 & 7 & 7 & XVI-XVII & $25-38$ & Dent cassice. Présence d' 1/2 lame \\
\hline MSL739 & M2 sup. g. & 14 & $-14 x$ & 6 & & 78 & & & B3 & 1,7 & 8,25 & 8 & XIV & $13-24$ & \\
\hline MSL157 & M2 sup. g. & 10 & $-10\left(x_{0}\right)$ & 10 & & 90 & & & c & 1.4 & 7.5 & 7.5 & XVI-XVII & $25-38$ & Cèment important \\
\hline MSL734 & M3 sup. y. & 8 & $\times 8$. & 0 & & 99 & 213 & 215 & A & & 6,25 & & XVII-XVIII & $25-38$ & \\
\hline MSL. 737 & M2/3 sup.d. & 7 & -7. & 7 & & 92 & & & c & 1,9 & 5,5 & 5,5 & & & \\
\hline MSL738 & M3 sup. d. & 9 & $\times 9-$ & 0 & & 100 & 190 & 190 & A & & & & XVII-XVIII & $25-38$ & Dans sa malrice osseuse \\
\hline MSL735 & M1:2 sup. g. & 7 & $\times 7$. & 0 & & 82 & & & $\mathrm{~A}$ & & 6,5 & & & & \\
\hline MSL736 & M sup. g. & 4 & $x 4-$ & 0 & & (80) & & & $\mathrm{A}$ & & & & $?$ & ? & \\
\hline MSL239 & M sup. & 3 & -3. & 0 & & & & & $?$ & & & & ? & ? & \\
\hline MSL119 & $\mathrm{M} 2 / 3$ & 1 & -1. & 0 & & (91) & & & ? & & & & ? & ? & \\
\hline MSL.120 & $\mathrm{M} 2 / 3$ sup. & 4 & -4. & 0 & & (88) & & & ? & & & & $?$ & $?$ & \\
\hline MSL519 & M inf. d. & 6 & $-6-$ & 0 & & & & & $?$ & & & & ? & ? & \\
\hline MSL741 & M2:3 sup. g. & 9 & -9 & 9 & & (76) & & & D1 & 1,7 & 7,5 & 7,5 & $?$ & $?$ & \\
\hline MSL 742 & M3 sup. d. & 9 & $\times 9$ & 7 & & 98 & 211 & 215 & 13.3 & 1,6 & 8,5 & 8 & XXI & $25-38$ & \\
\hline MSL 743 & M3 sup. g. & 16 & x $16-$ & 6 & & 100 & 223 & 223 & B2 & 1,6 & 8 & 8 & $\mathrm{xx}$ & $25-38$ & \\
\hline MSL 745 & M3 inf. d. & 8 & $\infty 8(\infty)$ & 8 & & (94) & & & $\mathrm{D} 2$ & 2,6 & & 5,25 & XXVII & $>47$ & \\
\hline MSL746 & M3 sup. d. & 12 & 12. & 6 & & 108 & 191 & 177 & B.3 & 2 & 6.25 & 7 & XXI & $25-38$ & \\
\hline MSL 749 & M3 sup. y. & 5 & $-5 x$ & 2 & & & & & D2 & 3 & 4.5 & & XXVII & $>47$ & Morphologic archä̈que \\
\hline MSL747 & M2 sup. d. & 9 & $x 9(\infty)$ & 9 & & 88 & & & D1 & 1,6 & 7,5 & 8,5 & XVIII & $25-38$ & \\
\hline MSL 748 & M sup, $g$. & 5 & $-5 x$ & 0 & & & & & & & 8 & & $?$ & ? & \\
\hline MSL 750 & M inf? & 9 & $-9-$ & 0 & & & & & & & 9 & & $?$ & & \\
\hline MSL812 & M3 inf. d. & 13 & $\times 13-$ & 5 & & 97 & 200 & 206 & 132 & 1,8 & 6 & 8 & $x x$ & $25-38$ & \\
\hline MSL1083 & M sup. & 3 & -3. & 0 & & & & & & 2.1 & 6 & & ? & & \\
\hline MSL1139 & M2 sup. g. & 9 & $\infty 9(\infty)$ & 9 & & (92) & & & D3 & 1,8 & 7,5 & 7,5 & XXI & $25-38$ & \\
\hline MSL.531 & M sup. & 2 & $-2-$ & () & & & (16i) & & & 1,4 & & & $?$ & $?$ & \\
\hline MSL575 & $?$ & 1 & -1. & 0 & & & & & & 2 & & & $?$ & $?$ & Fragment de lame \\
\hline MSL576 & ? & 1 & -1 . & 0 & & & & & & 1,7 & & & $?$ & $?$ & Fragment de lame \\
\hline MSL.1196 & $?$ & 1 & -1. & $?$ & & & & & & & & & $?$ & ? & Fragment de lame \\
\hline MSL1197 & ? & 1 & -1 . & 0 & & & & & & & & & $?$ & ? & \\
\hline MSL521 & ? & 1 & $-1-$ & 1 & & & & & & 1,8 & & & $?$ & $?$ & \\
\hline HSWS85001 & $\mathrm{M} 1 / 2$ & 7 & $x ;(x)$ & 7 & & (69) & & & D3 & 2 & 9 & 9 & & & \\
\hline HSMS85004 & M2 sup. d. & 15 & (x) $15 x$ & 13 & 220 & 92 & & & c & 2,3 & 7 & 7,25 & XVI-XVII & 25-38 & \\
\hline HSMS76391 & M3 sup. g. & 10 & $\infty 10 x$ & 10 & & (86) & & & D2 2 & 2 & 6,75 & 6 & XXVII & $>47$ & \\
\hline MSL 727 & MI sup. g." & 8 & $\infty 8$ & 8 & & 73 & & & CDI & 1.5 & 9 & 8 & $\mathrm{XI}-\mathrm{XII}$ & $13-24$ & Doute M. primigenius (Lister, 1994) \\
\hline
\end{tabular}

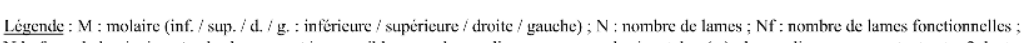

Nd : formule laminaire ; + : des lames sont inaccessibles; $\infty$ : lames disparu par usure horizontale ; $(\infty)$ : lames disparu par contact entre 2 dents ; - : cassure ; $\mathrm{x}$ : lamelle. Li : longueur de la couronne dentaire (en mm), I: largeur, $\mathrm{H}:$ hauteur maximale, $\mathrm{h}:$ indice d'hypsodontie $\mathrm{h}-\mathrm{H} / \mathrm{I} \times 100$.

Laws: Groupes d'âge définis par Laws. Âge en années 


\begin{tabular}{|c|c|c|c|c|c|c|c|c|c|c|c|c|c|c|c|}
\hline$\underline{V}$ pièce & Phote Pasition dent & $n$ & $\mathrm{Nd}$ & $\mathrm{Nr}$ & Li & 1 & II & $\mathrm{h}$ & u & e & F lat. & F occl. & Laws & Age approx. & Remarques \\
\hline \multirow[t]{4}{*}{$89 \mathrm{HSO62}$} & M2 sup. g. & 11 & $\infty, 11$ & 11 & & 70 & & & $\mathrm{D} 2$ & 2,3 & & 7,5 & $\mathrm{xX}$ & $25-38$ & Cément des M3 important \\
\hline & M3 sup. g. & $>3$ & $(\infty) 3^{+}$ & 3 & & (70) & & & B2 & 2,3 & & & & & \\
\hline & M2 sup. d. & 11 & $\infty 11$ & 11 & & 72 & & & D2 & 2,3 & & 7 & & & \\
\hline & M3 sup. d. & $=3$ & $(\infty)^{3-}$ & 3 & & (70) & & & $\mathrm{B} 2$ & 2,3 & & & & & \\
\hline \multirow[t]{4}{*}{83.1408} & $\mathrm{M} 2$ inf. $\mathrm{g}$. & 12 & $\infty 12$ & 11 & & 72 & & & c & 2,3 & & 7 & XVII & $25-38$ & \\
\hline & M3 inf. g. & $>13$ & $13-$ & 0 & & 85 & & & A & & & & & & \\
\hline & $\mathrm{M} 2$ inf. d. & 13 & $\infty 13$ & 13 & & 72 & & & c & 2,3 & & 7 & & & \\
\hline & M3 inf. d. & $\$ 15$ & $15-$ & 0 & & & & & A & & & & & & \\
\hline \multirow[t]{3}{*}{ Sans $\mathrm{N}^{\circ} 3$} & M2 sup. d. & 11 & $\infty 11$ & 11 & (205) & 75 & & & DI & 2.5 & & 6 & XVIII & $25-38$ & \\
\hline & M3 sup, d. & $?$ & & 0 & & & & & A & & & & & & \\
\hline & M2 sup. g. & 12 & $\approx=12$ & 12 & & 75 & & & DI & 2.5 & & 6,5 & & & \\
\hline \multirow[t]{4}{*}{$06 \mathrm{HS}$} & $\mathrm{M} 2$ inf. d. & 9 & $\infty 9\left(x_{0}\right)$ & 9 & & (74) & & & $\mathrm{D} 2$ & 2,5 & & 7 & $x x$ & $25-38$ & \\
\hline & M3 inf. d. & $>7$ & $\times 7$ & 5 & & (85) & & & B2 & 2,4 & & 8 & & & \\
\hline & $\mathrm{M} 2 \mathrm{inf} \mathrm{p}$. & 9 & $\infty y(x)$ & 9 & & (72) & & & $\mathrm{D} 2$ & 2,5 & & 7 & & & \\
\hline & M3 inf. g. & $>10$ & $\times 10^{-}$ & 3 & & (78) & & & B2 & 2,4 & & 8 & & & \\
\hline \multirow[t]{2}{*}{ Sans $N^{\circ} 4$} & M2 inf. d. & $>13$ & $\infty 13+$ & 12 & & 70 & & & $\mathrm{C}$ & 2,7 & & 7 & $\mathrm{xVII}$ & $25-38$ & \\
\hline & $\mathrm{M} 2 \mathrm{inf}$. g. & $>13$ & $\infty 13+$ & 12 & & 75 & & & c & 2,7 & & 7 & & & \\
\hline \multirow[t]{4}{*}{$89 \mathrm{HS} 033$} & M2 sup. d. & 12 & $\infty 12(\infty)$ & 12 & & 90 & & & $\mathrm{Dl}$ & 2,4 & & 6,5 & XVIII & $25-38$ & \\
\hline & M2 sup. g. & 8 & $-8(\propto)$ & 8 & & 85 & & & D1 & 2,4 & & 6,5 & & & \\
\hline & M3 sup. d. & $?$ & $?$ & 0 & & (95) & & & A & & & & & & \\
\hline & M3 sup. g. & $?$ & $?$ & 0 & & (95) & & & A & & & & & & \\
\hline \multirow[t]{2}{*}{ Sans $\mathrm{N}^{\circ} 5$} & M3 inf. d. & $\rightarrow 11$ & $11+$ & 10 & & 88 & & & $\mathrm{~B}_{3}$ & 2.2 & & 6,5 & $\mathrm{xXI}$ & $25-38$ & M3 inf. g. concrétionnéc \\
\hline & M3 inf, $y$. & $?$ & $?$ & $?$ & & & & & $?$ & 2.2 & & , & $x_{x}$ & ..... & 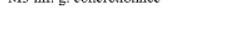 \\
\hline \multirow[t]{5}{*}{ Sans $\mathrm{N}^{\circ} 6$} & Ml inf. g. & 4 & $x=4(x)$ & 4 & & (64) & & & D4 & 2 & & & XVI-XVII & $25-38$ & \\
\hline & M2 inf. g. & 15 & $(x)$ is & 14 & & (70) & & & $\mathrm{C}$ & 2 & 8.75 & 9 & & & \\
\hline & M2 inf. d. & 15 & $\left(x_{0}\right) 15$ & 14 & & (66) & & & c & 2,1 & 7.75 & 8 & & & \\
\hline & M3 inf. g. & 4 & 4. & 0 & & (80) & & & A & & & & & & \\
\hline & M3 inf. d. & 12 & 12 & 0 & & (96) & & & A & & & 8 & & & \\
\hline \multirow[t]{6}{*}{ Sans $N^{\prime \prime} 7$} & M1 inf. d. & 6 & $\infty, 6(x)$ & 6 & & (59) & & & D3 & 2,5 & & 8 & xv & $13-24$ & \\
\hline & M2 inf. d. & 14 & $(x) 14$ & 12 & (210) & (71) & & & B4 & 2,2 & & 8 & & & \\
\hline & M1 inf. g. & 5 & $\infty 5(\infty)$ & 5 & & (57) & & & D3 & 2,5 & & 8 & & & \\
\hline & M2 inf. g. & 14 & 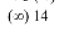 & 11 & (215) & (74) & & & B4 & 2,2 & & 8 & & & \\
\hline & M3 inf. d. & $?$ & ?. & 0 & & & & & $\mathrm{~A}$ & & & & & & \\
\hline & M3 inf. g. & $?$ & ?. & 0 & & & & & A & & & & & & \\
\hline \multirow[t]{3}{*}{83.216} & M2 sup. d. & 15 & $\infty 15$ & 13 & (215) & 85 & & & c & 2 & & 7 & XVI-XVII & $25-38$ & 1 lame se divise en 2 cởé vestibulaire \\
\hline & M2 sup. g. & 15 & $\infty 15$ & 13 & (222) & 85 & & & c & 2 & & 7 & & & \\
\hline & M3 sup. d. & $?$ & $?$ & 0 & & & & & A & & & & & & \\
\hline \multirow[t]{2}{*}{ Sans $\mathrm{N}^{\circ} 18$} & M. inf. g. & $?$ & $\times 7-$ & 0 & & 75 & (145) & 193 & A & & 7.5 & & $?$ & ? & \\
\hline & M3 sup. d. & $?$ & & 0 & & & & & A & & & & & & \\
\hline Sans $\mathrm{N}^{\circ} 8$ & $\begin{array}{l}\text { M3 s spp. . } \\
\text { M3 sup. d. }\end{array}$ & 20 & $\infty 220$. & 11 & 375 & 106 & 205 & 193 & $\begin{array}{l}134 \\
134\end{array}$ & $\begin{array}{l}2,9 \\
2,9\end{array}$ & $\begin{array}{l}0.25 \\
6\end{array}$ & 5,75 & & $39-4 i$ & \\
\hline
\end{tabular}

\begin{tabular}{|c|c|c|c|c|c|c|c|c|c|c|c|c|c|c|c|}
\hline \multirow{3}{*}{$\frac{N^{\circ} \text { plcce }}{\text { HS00140/79.249 }}$} & Photo Position dent & $\mathrm{N}$ & $\mathrm{Nd}$ & $\mathrm{Nf}$ & $\mathrm{Li}$ & 1 & $\mathrm{H}$ & $\mathrm{h}$ & u & $c$ & F lat. & Foccl & Laws & Agc approx & Remarques \\
\hline & Fig. 7 M3 inf. g. & $>15$ & $15+$ & 12 & $(256)$ & 84 & & & B4 & 2,5 & & 6,5 & XXIII & $39-47$ & Scule mâchoire entière attestéc \\
\hline & $\mathrm{M} 3$ inf $\mathrm{d}$. & $>15$ & $15+$ & 12 & (256) & 84 & & & B4 & 2,6 & & & & & \\
\hline & M3 sup. g. & $=14$ & $14+$ & $10-$ & (240) & 85 & & & B4 & $?$ & & $7 ?$ & & & \\
\hline \multirow[t]{4}{*}{$\mathrm{HS} 00146 / 79,265$} & Fig. 7 MI sup, d. & 8 & $\infty 8(x)$ & 8 & & (69) & & & D3 & 2,7 & & 8,5 & $\mathrm{xV}$ & $13-24$ & \\
\hline & M2 sup, d. & $>13$ & (x) $13+$ & 9 & (200) & (70) & 122 & 174 & B4 & 2,6 & & 9 & & & \\
\hline & M1 sup, g. & 7 & $\infty 7(x)$ & 7 & & (70) & & & D4 & 2,7 & & 8 & & & \\
\hline & M2 sup. g. & $>13$ & (x) $13+$ & 9 & (187) & (6.3) & 120 & 190 & B34 & 2,6 & & 9 & & & \\
\hline \multirow[t]{2}{*}{ HS0020.3 } & M3 sup, d. & 15 & $\circ 15$ & 13 & (230) & 97 & & & $\mathrm{c}$ & 2,7 & 7,7 & & XXIV-XXv & $39-47$ & \\
\hline & M3 sup. g. & 15 & 00 & 12 & (230) & 100 & & & $c$ & 2,7 & 7,7 & & & & \\
\hline \multirow[t]{2}{*}{ HS00147/79.203 } & Fig. 7 M2 sup. d. & 13 & $\infty 13$ & 12 & (185) & 78 & (130) & 167 & c & 2,4 & 7 & 7,5 & $\mathrm{xVI}$ & $25-38$ & La cavitè de la M3 g. est présente \\
\hline & M2 sup. g. & 13 & $\infty 13$ & 12 & (185) & 77 & & & c & 2,4 & 7 & 7,5 & & & \\
\hline \multirow[t]{2}{*}{ Sans $\mathrm{N}^{\mathrm{a}} 1$} & MI inf d. & $\geqslant 10$ & $=10+$ & 10 & & 62 & & & $\mathrm{c}$ & 2,3 & 7 & & $\mathrm{XI}$ & $13-24$ & \\
\hline & $\mathrm{M} 1$ inf $g$. & $\geqslant 10$ & $\infty 10+$ & 10 & & 63 & & & $\mathrm{c}$ & 2,3 & 7 & & & & \\
\hline \multirow[t]{4}{*}{$\mathrm{HS} 00283 / 76.375$} & Fig. 7 M2 inf. d. & 11 & $\infty 11(\infty)$ & 11 & & 82 & & & D2 & 2,2 & & 7 & $\mathrm{xXI}$ & $25-38$ & \\
\hline & M3 inf. d. & $>15$ & $15+$ & 9 & & (72) & & & В3 & 2 & & 8,5 & & & \\
\hline & M2 inf. $g$. & 11 & $\infty 11(\alpha)$ & 11 & & 85 & & & D2 & 2,2 & & 7 & & & \\
\hline & M3 inf. $\mathrm{g}$. & $>15$ & $15+$ & 9 & & (70) & & & B3 & 2 & & 8,5 & & & \\
\hline \multirow[t]{4}{*}{ HS03036 } & M2 inf. d. & 13 & $\infty 13$ & 12 & & 76 & & & c & 2,5 & & 6,5 & XVII & $25-38$ & \\
\hline & M2 inf. $g$. & 13 & $x_{0} 13$ & 12 & & 78 & & & $\mathrm{C}$ & 2,5 & & 6,5 & & & \\
\hline & $\mathrm{M} 3 \mathrm{int} \mathrm{d}$. & $?$ & $?$ & 0 & & & & & A & & & & & & \\
\hline & M 3 inl. g. & $?$ & $?$ & 0 & & & & & A & & & & & & \\
\hline \multirow[t]{4}{*}{ Sans $\mathrm{N}^{\prime \prime} 2$} & M2 sup. d. & 5 & $\infty 5(\infty)$ & 5 & & (8.3) & & & D3 3 & 2,3 & & 6 & $\mathrm{xxI}$ & $25-38$ & \\
\hline & M3 sup. d. & 17 & 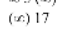 & 6 & 300 & 45 & (1810) & 189 & 133 & 2,3 & 7 & 6,5 & & & \\
\hline & M2 sup. g. & 5 & $\infty 5(\infty)$ & 5 & & (83) & & & D3 & 2,3 & & & & & \\
\hline & M3 sup. g. & 16 & (க) 16 - & 7 & 294 & 100 & (163) & 163 & B3 & 2,3 & 7,25 & 6,5 & & & \\
\hline \multirow[t]{2}{*}{$\mathrm{HS} 00336 / \mathrm{S} 76$} & M2 sup. d. & 10 & $\infty 10(x)$ & 10 & & 92 & & & D1 & 1,8 & & 8 & xVIIII & $25-38$ & Contact avec M3 manquantes \\
\hline & M2 sup. g. & 12 & $\infty 12(\infty)$ & 12 & & 93 & & & D1 & 1,8 & & 8 & & & \\
\hline \multirow[t]{4}{*}{83.1107} & $\mathrm{M} 2 \mathrm{inf}$. $\mathrm{d}$. & 13 & $\infty 13$ & 13 & & 73 & & & D1 & 2,3 & & 7 & XVIII & $25-38$ & \\
\hline & M3 inf. d. & ? & $\times ?$ & 0 & & & & & $\mathrm{~A}$ & & & & & & \\
\hline & M2 inf. $\mathrm{g}$. & 13 & $\infty 13$ & 13 & & 73 & & & D1 & 2,3 & & 7 & & & \\
\hline & $\mathrm{M} 3 \mathrm{inf} g$. & $?$ & $\times ?$ & 0 & & & & & $\mathrm{~A}$ & & & & & & \\
\hline \multirow[t]{4}{*}{83.166} & M2 sup. d. & $>13$ & $\times 13+$ & 13 & & 82 & & & $\mathrm{c}$ & 2,4 & & 7,75 & XVII & $25-38$ & 1 lame M2 se divise en 2 côté lingual \\
\hline & M2 sup. g. & $>13$ & $\infty 13+$ & 13 & & 84 & & & $\mathrm{c}$ & 2,4 & & 7,75 & & & \\
\hline & M3 sup. d. & $?$ & $x ?$ & 0 & & & & & A & & & & & & \\
\hline & M.3 sup. g. & $?$ & $\mathrm{x}$ ? & 0 & & & & & $\mathrm{~A}$ & & & & & & \\
\hline \multirow[t]{2}{*}{83.215} & $\mathrm{M} 2 \mathrm{inf} \mathrm{d}$. & 11 & $x: 11$ & 11 & & 68 & & & D1 & 1,9 & & 7,5 & xVIII & $25-38$ & \\
\hline & M2 inf. g. & 11 & $\approx 11$ & 11 & & 70 & & & D1 & 1,9 & & 7,5 & xvIII & $25-36$ & \\
\hline \multirow[t]{2}{*}{ 962 HS216? } & M2 sup. d. & $>12$ & $\infty 12+$ & 12 & & 76 & & & c & 2,1 & & 7,5 & XVII & $25-38$ & \\
\hline & M2 sup. g. & $\geqslant 13$ & $\infty 13+$ & 13 & & 76 & & & c & 2,1 & & 7,5 & & & \\
\hline \multirow[t]{2}{*}{ HSO030 } & $\mathrm{M} 2 / 3 \mathrm{inf} \mathrm{g}$. & $>10$ & $10+$ & 10 & & (70) & & & B4 & 2,3 ? & & 7 & $?$ & ? & Lecture de $\mathrm{c}$ difficile \\
\hline & $\mathrm{M} 2 / 3 \mathrm{inf}$. d. & $>11$ & $11+$ & 11 & & (70) & & & B4 & $2,3 ?$ & & 7 & & & \\
\hline
\end{tabular}




\begin{tabular}{|c|c|c|c|c|c|c|c|c|c|c|}
\hline$N^{\circ}$ picese & Photo & jugals & Mandibule & Maxillaire & Laws & Age approx & & F lat. & F occl. & Remarques \\
\hline $\mathrm{HS} 00140 / 79.249$ & Fig. 7 & 3 & M3 (dg) & M3 (g) & XXIII & $39-47$ & 2,6 & & 6,5 & Seule mâchoire entière attestéé \\
\hline HS00146/79.265 & Fig. 7 & 4 & & $\mathrm{M} 1-\mathrm{M} 2$ (dg) & $\mathrm{xV}$ & $13-24$ & 2,7 & & 9 & \\
\hline IIS002033 & & 2 & & M3 $(d g)$ & XXIV-XXV & $39-47$ & 2,7 & 7,7 & & \\
\hline HSO0147/79.203 & Fig. 7 & 2 & & $\mathrm{M} 2$ (dg) & XVI & $25 \cdot 38$ & 2.4 & 7 & 7.5 & La cavité de la M3 g. cst présente \\
\hline Sans $N^{\circ} 1$ & & 2 & M1 (dg) & & $\mathrm{XI}$ & $13-24$ & 2,3 & 7 & & \\
\hline $\operatorname{Sans} N^{\circ} 13$ & & $1^{*}$ & M2 (d) & & XVIII & $25-38$ & 2,3 & & 6,5 & \\
\hline HSO01297 & & 1" & & $\mathrm{M}$ (d) & $?$ & $?$ & $?$ & 7 & & \\
\hline Sans $\mathrm{N}^{\circ} 14$ & & $1^{*}$ & & $\mathrm{M}$ & XVIII-XXX & $>30$ & 2,6 & 7 & & Encore enfouic dans le sédiment \\
\hline 115012016 & & 1 & & $\mathrm{M}(\mathrm{g})$ & & & $?$ & & 7 & Coincée entre maxillaire et sédiment \\
\hline HS $00283 / 76.375$ & Fig. 7 & 3 & $\mathrm{M} 2+\mathrm{M} 3(\mathrm{dg})$ & & $\mathrm{XXI}$ & $25-38$ & 2,2 & & 7,75 & \\
\hline HS03036 & & 3 & $\mathrm{M} 2+\mathrm{M} 3(\mathrm{dg})$ & & xvII & $25-38$ & 2,5 & & 6,5 & \\
\hline $05 \mathrm{HS} 105$ & & $1^{*}$ & & $\mathrm{M}$ & $?$ & $?$ & & & & \\
\hline Sans $\mathrm{N}^{\circ} 2$ & & 4 & & $\mathrm{M} 2+\mathrm{M} 3(\mathrm{dg})$ & $\mathrm{xxI}$ & $25-38$ & 2,3 & 7 & 6,25 & \\
\hline $\mathrm{HS} 00336 / \mathrm{S} 76$ & & 2 & & $\mathrm{M} 2(\mathrm{dg})$ & XVIII & $25-38$ & 1,8 & & 8 & Contact avec M3 manquante \\
\hline 83.1107 & & 4 & $\mathrm{M} 2+\mathrm{M} 3(\mathrm{dg})$ & & xVIII & $25-38$ & 2,3 & & 7 & \\
\hline 83.166 & & 4 & & $\mathrm{M} 2-\mathrm{M} 3(\mathrm{dg})$ & XVII & $25-38$ & 2.4 & & 7,75 & 1 lanme M2 $2 \mathrm{sedivisc} \operatorname{cn} 2$ còté lingual \\
\hline 83.215 & & 2 & M2 (dg) & & XVIII & $25-38$ & 1,9 & & 7,5 & \\
\hline HS00706? & & 1 & & $\mathrm{M} 2$ (d) & XVII & $25-38$ & 2,6 & & 7,5 & Scule encore en place dans le maxillaire \\
\hline HS00408 / HSO0082 & & 1 & & M2 (g) & XVIII & $25-38$ & 2,6 & & 6 & Seule encore en place dans le maxillaire \\
\hline $962 \mathrm{HS} 216 ?$ & & 2 & & M2 (dg) & XVII & $25-38$ & 2,1 & & 7,5 & \\
\hline HS(01030 & & 2 & $\mathrm{M} 2 / 3(\mathrm{dg})$ & & $x V-x x I I I$ & 24 ou 41 & 2,3 & & 7 & Lecture de e difficile \\
\hline $90 \mathrm{HS} 02$ & & $1^{s}$ & & $\mathrm{M} 2 / 3$ & $?$ & $?$ & 2,2 & & 7 & En partic masquúc par le sédimcnt \\
\hline 89115062 & & 4 & & $\mathrm{M} 2+\mathrm{M} 3(\mathrm{dg})$ & $x x$ & $25-38$ & 2,3 & & 7,25 & Cément des $\mathrm{M} 3$ important \\
\hline 83.1408 & & 4 & $\mathrm{M} 2+\mathrm{M} 3(\mathrm{dg})$ & & XVII & $25-38$ & 2,3 & & 7 & \\
\hline Sans $\mathrm{N}^{\circ} 3$ & & 3 & & $\mathrm{M} 2(\mathrm{dg})+\mathrm{M} 3(\mathrm{~d})$ & xVIII & $25-38$ & 2,5 & & 6,25 & \\
\hline $06 \mathrm{HS}$ & & 4 & $\mathrm{M} 2+\mathrm{M} 3(\mathrm{dg})$ & & $\mathrm{xx}$ & $25-38$ & 2,5 & & 7,5 & \\
\hline Sans $N^{\circ} 4$ & & 2 & $\mathrm{M} 2(\mathrm{dg})$ & & xVII & $25-38$ & 2,7 & & 7 & \\
\hline Sans $\mathrm{N}^{\circ} 15$ & & 1 & & & XV-XXIII & 24 ou 41 & 2,8 & & 6 & Hémi-mandibule sortant du sédiment \\
\hline 89015033 & & 4 & & $\mathrm{M} 2+\mathrm{M} 3(\mathrm{dg})$ & XVIII & $25-38$ & 2,4 & & 6,5 & \\
\hline Sans $\mathrm{N}^{\circ} 5$ & & 2 & M3 (dg) & & XXI & $25-38$ & 2,2 & & 6,5 & M3 inf. g. concrétionnéc \\
\hline Sans $\mathrm{N}^{\circ} 17$ & & 1 & & M3 & $?$ & & & & & Accessibilité gênée dans le maxillaire \\
\hline MSL692 & & $1^{*}$ & & M2 (g) & XVI-XVII & $25-38$ & 1,8 & 7 & 7 & Dent casséc. Présence d' 1/2 lame \\
\hline MSL 727 & & 1 & & M1 (g.?) & $\mathrm{XI}$ & $13-24$ & 1,5 & 9 & 8 & Doute M2 M.primigenius (Lister,1994) \\
\hline MSL739 & & $1^{8}$ & & $\mathrm{M} 2(\mathrm{~g})$ & xIV & $13-24$ & 1,7 & 8,25 & 8 & \\
\hline MSL.157 & & $1^{\circ}$ & & M2 (g) & xv1-xvıl & $25-38$ & 1,4 & 7,5 & 7,5 & Cément important \\
\hline MSL734 & & $1^{*}$ & & M3 (g) & XVII-XVIII & $25-38$ & & 6,25 & & \\
\hline MSL. 737 & & 1" & & $\mathrm{M} 2 / 3(\mathrm{~d})$ & XYI-XXY & 27 ou 46 & 1,9 & 5,5 & 5,5 & \\
\hline MSL738 & & $1^{8}$ & & M3 (d) & XVII-XVIII & $25-38$ & & & & Dans sa matricc osscusc \\
\hline MSL735 & & 1" & & $\mathrm{Ml} / 2(\mathrm{~g})$ & VII-XI & 6 ou 15 & & 6,5 & & \\
\hline Sans $N^{\circ} 18$ & & $1^{*}$ & $\mathrm{M}(\mathrm{g})$ & & $?$ & $?$ & & 7,5 & & \\
\hline Sans $\mathrm{N}^{\sigma} 12$ & & 2 & $\mathrm{M} 2+\mathrm{M} 3$ (d) & & XVl-XvII & $25-38$ & 1,86 & & 6,75 & \\
\hline MSL736 & & $1^{8}$ & & $\mathrm{M}(\mathrm{g})$ & $?$ & $?$ & & & & \\
\hline MSL 239 & & 1" & & $\mathrm{M}$ & $?$ & $?$ & & & & \\
\hline
\end{tabular}

Table 4 - Mammuthus columbi dental series data, Hot Springs.

\begin{tabular}{|c|c|c|c|c|c|c|c|c|c|}
\hline $\mathrm{N}^{\circ}$ piece & Photo $\mathrm{Nb}$ jugale: & Mandibule & Maxillaire & Laws & Age approz & & $F$ lat. & F occl. & Remargues \\
\hline MSL119 & $1^{*}$ & & $\mathrm{M} 2 / 3$ & $?$ & $?$ & & & & \\
\hline MSL.120 & $1^{*}$ & & $\mathrm{M} 2 / 3$ & ? & $?$ & & & & \\
\hline MSL519 & $1^{*}$ & $M(d)$ & & $?$ & ? & & & & \\
\hline MSL 741 & $1^{*}$ & & $\mathrm{M} 2 / 3(\mathrm{~g})$ & $?$ & $?$ & 1,7 & 7,5 & 7,5 & \\
\hline MSL 742 & $1^{*}$ & & M3 (d) & $x \times 1$ & $25-38$ & 1,6 & 8,5 & 8 & \\
\hline MSL 743 & $1^{*}$ & & M3 (g) & $\mathrm{XX}$ & $25-38$ & 1,6 & 8 & 8 & \\
\hline MSL 745 & $1^{*}$ & M3 (d) & & XXVII & $>47$ & 2,6 & & 5,25 & \\
\hline MSL 746 & $1^{*}$ & & $\mathrm{M} 3(\mathrm{~d})$ & $\mathrm{XXI}$ & $25-38$ & 2 & 6.25 & 7 & \\
\hline MSL 749 & $1^{*}$ & & M3 (g) & XXVII & $>47$ & 3 & 4.5 & & Morphologie archaīgue \\
\hline MSL 747 & $1^{*}$ & & M2 (d) & XVIII & $25-38$ & 1,6 & 7,5 & 8,5 & \\
\hline MSL 748 & $1^{*}$ & & $M(g)$ & ? & $?$ & & 8 & & \\
\hline MSL 750 & $1^{*}$ & M & & $?$ & $?$ & & 9 & & \\
\hline MSL 812 & $1^{*}$ & M3 (d) & & $\mathrm{xx}$ & $25-38$ & 1,8 & 6 & 8 & \\
\hline MSL1083 & $1^{*}$ & & $\mathrm{M}$ & $?$ & & 2,1 & 6 & & \\
\hline MSL 1139 & $1^{*}$ & & M2 (g) & $\mathrm{xXI}$ & $25-38$ & 1,8 & 7.5 & 7,5 & \\
\hline MSLS31 & $1^{*}$ & & $\mathrm{M}$ (马) & $?$ & $?$ & 1,6 & & & \\
\hline MSL575 & 1 & & & ? & ? & 2 & & & Fragment de lame \\
\hline MSL 576 & 1 & & & ? & ? & 1,7 & & & Fragment de lame \\
\hline MSI.1196 & 1 & & & $?$ & ? & & & & Fragment de lame \\
\hline MSL1197 & 1 & & & ? & ? & & & & \\
\hline MSL521 & 1 & & & $\%$ & $?$ & 1,8 & & & \\
\hline IISMS85001 & 1 & & & XIV-XXI & 22 ou 36 & 2 & 9 & 9 & \\
\hline HSMS 85004 & $1^{*}$ & & M2 (d) & XVI-XVII & $25-38$ & 2,3 & 7 & 7.25 & \\
\hline HSMS76391 & $1^{*}$ & & M3 (g) & XXVII & $>47$ & 2 & 6,75 & 6 & \\
\hline Sans $\mathrm{N}^{\circ} 6$ & 5 & $\mathrm{M} 1(\mathrm{~g})-\mathrm{M} 2+\mathrm{M} 3(\mathrm{dg})$ & & XVl-XVII & $25-38$ & 2,1 & 8.25 & 8,5 & \\
\hline Sans $\mathrm{N}^{\circ} 7$ & 6 & $\mathrm{M} 1+\mathrm{M} 2+\mathrm{M} 3$ (dg) & & XV & $13-24$ & 2,3 & & 8 & \\
\hline 83.216 & 4 & & $\mathrm{M} 2+\mathrm{M} 3(\mathrm{dg})$ & XVI-XVII & $25-38$ & 2 & & 7 & 1 lame se divise en 2 côté vestibulaire \\
\hline Sans $\mathrm{N}^{\circ} 8$ & 2 & & M3 (dg) & $\mathrm{XXIII}$ & $39-47$ & 2,9 & 6 & 6 & \\
\hline 78.157 & 4 & & $\mathrm{M} 2+\mathrm{M} 3(\mathrm{dg})$ & $x x$ & $25-38$ & 2,4 & 7 & 6,5 & \\
\hline MSL 1172 & 4 & $\mathrm{M} 2+\mathrm{M} 3(\mathrm{dg})$ & & XVI-XVII & $25-38$ & 3,2 & 4,25 & 4,75 & Cément important \\
\hline Sans $\mathrm{N}^{\circ} 9$ & 4 & $\mathrm{M} 2+\mathrm{M} 3(\mathrm{~g})$ & & XV1-XVII & $25-38$ & 2,4 & & 7 & \\
\hline Sans $N^{\circ} 16$ & 1 & M3 (d) & & xxv1 & $>47$ & 2,3 & & 6,5 & Seule dans l'hémi-mandibule. Cément + \\
\hline Sans $\mathrm{N}^{\circ} 10$ & 2 & M3 (dg) & & XXIII & $39-47$ & 2,9 & & 5,5 & \\
\hline $87.523 /$ तै 108 & 4 & $\mathrm{M} 2+\mathrm{M} 3(\mathrm{dg})$ & & $\mathrm{XXI}$ & $25-38$ & 3,3 & & 6.75 & Cément des M3 important \\
\hline Sans $\mathrm{N}^{0} 11$ & 4 & $\mathrm{M} 2+\mathrm{M} 3(\mathrm{dg})$ & & XVIII & $25-38$ & 2,5 & & 6 & Cément des M2 important \\
\hline MSL.744/85.0102 & 2 & & $\mathrm{M} 2+\mathrm{M} 3(\mathrm{~g})$ & XVI-XVII & $25-38$ & 2,8 & & 7,5 & Cément de la $\mathrm{Y} 2$ important \\
\hline HS00035 / MSL937 & 3 & $\mathrm{Ml}$ (d) + M2 (dg) & & XVI & $25-38$ & 2,4 & & 8 & Cément des M2 important \\
\hline Sans $\mathrm{N}^{\circ} 19$ & $1^{*}$ & & M3 (g) & $\mathrm{xx}$ & $25-38$ & 1.88 & 6.5 & 8 & \\
\hline "Manfred" & 3 & & $\mathrm{M} 2(\mathrm{dg})+\mathrm{M} 3(\mathrm{~g})$ & XVI-XVII & $25-38$ & 2,4 & & 7 & \\
\hline
\end{tabular}

Légende : M2/3 : M2 (avant dernière molaire) ou M3 (dernière molaire). $\mathrm{M} 2+\mathrm{M} 3$ (dg) : M2 et M3 droites et gauches.

Nombre de jugales : « 1 » dent isolée, « $1^{*}$ » dent seule en place dans le maxillaire ou la mandibule ; $\mathrm{F}$ : fréquence laminaire (lames sur $10 \mathrm{~cm}$ ), mesure latérale et occlusale.

\section{Legend of tables 3 and 4}

Isolated tooth / dental series

Isolated tooth: not in bone.

Series: composed of at least two teeth. 


\section{Tooth position}

D2 to D4 are deciduous teeth and M1 to M3 are molars (sometimes m1 to m6). inf. / sup. / d. / g.: inferior / superior / right / left.

\section{Number of cheek teeth}

« $1 »=$ isolated tooth (no bone); « $1 * »=$ one tooth in the bone.

\section{Mandible/Maxillary}

M2/3: M2 (last-but-one molar) or M3 (last molar).

M2 + M3 (dg): M2 and M3 right and left.

\section{Lamellas number}

$\mathrm{N}$ : total number of preserved lamellas (except for the last, smallest: Maglio, 1973). $\mathrm{Nd}$ : lamellar formula. A number preceded by " " means that part of the lamellas is inaccessible (hidden by the jaw for example), the tooth has at least " $\infty$ " that lamellas disappeared by contact (pressure) between 2 pre-eruption molars (Haynes, 1991), " $\infty$ " indicates the tooth is broken, " $x$ " the small lamella (first or last blade)

$\mathrm{Nf}$ : number of functional opened lamellas.

\section{Biometry and morphology of the molar}

$\mathrm{Li}$ : maximal length of the dental base, in $\mathrm{mm}$. (Li) : length of the worn tooth.

Lo : length of occlusal surface ; (Lo) length of occlusal surface of the worn tooth.

1 : maximal width, en $\mathrm{mm} /(\mathrm{l})$ : maximal width of occlusal surface.

$\mathrm{H}$ : height of the tallest unworn lamella, en mm (only for new tooth

or few worn).

$\mathrm{h}=\mathrm{H} / \mathrm{l} \times 100$.

$\mathrm{u}$ : Attrition levels (A : new tooth ; B to D : worn levels). e : enamel thickness, in mm.

$\mathrm{F}$ : lamellar frequency (number of lamellas on $10 \mathrm{~cm}$ ) ; occl. =

occlusal ; lat. = lateral (Maglio, 1973).

\section{Age groups}

Estimation according to Laws, 1966: II : 6 months, III : 1 year, IV :

$2 \mathrm{y}, \mathrm{VI}: 4+/-1 \mathrm{y}, \mathrm{VII}: 6+/-1 \mathrm{y}, \mathrm{IX}: 10+/-1 \mathrm{y}, \mathrm{X}: 13+/-1 \mathrm{y}, \mathrm{XI}: 15$

$+/-1 \mathrm{y}, \mathrm{XII}: 18+/-1 \mathrm{y}, \mathrm{XIII}: 20+/-2 \mathrm{y}, \ldots, \mathrm{XXI}: 36+/-2 \mathrm{y}, \mathrm{XXII}: 39$

$+/-2 \mathrm{y}$, XXIII : $43+/-2 \mathrm{y}$, XXIV : $45+/-2 \mathrm{y}, \mathrm{XXVI}: 49+/-2 \mathrm{y}, \mathrm{XXVII}$ :

$53+/-2 \mathrm{y}$, XXVIII : $55+/-4 \mathrm{y}, \mathrm{XXIX}: 57+/-4 \mathrm{y}, \mathrm{XXX}: 60+/-4 \mathrm{y}$.

Age classes: $<2$ years, 2 to 5,6 to 12,13 to 24,25 to 36,37 to

$48,>48$ years.

\section{ABSTRACTS}

Hot Springs, South Dakota, is unmistakably one of the richest sites in mammoth remains ever discovered in situ. The late Pleistocene site corresponds to an ancient swamp coming from an artesian well. The spring, whose temperature was constantly $35^{\circ} \mathrm{C}$, was providential during the glacial period for animals providing a nearby green vegetation all year round. However, the spring was a pitiless trap for animals venturing there, as it ended in a swallow hole in his submerged part. Thus, almost 26,000 years BP, many animals let themselves get trapped, especially mammoths. In order to understand this phenomenon, this work will analyse in the population structure of Proboscids. In order to define some age groups, the dental attrition method was applied, based on the position of each tooth in the cheek teeth series, as well as its 
worn level. The revision of Mammuthus Columbi mortality profile drawn up in 1994, thanks to the new datas collected on the site and submitted here, indicates that 22 of the 36 subjects identified according to their cheek teeth, were approximately 25-38 years old. The deficit of seniles associated with the lack of young individuals is surprising. The trap affected mostly adult subjects. This unusual population structure characterises no known model. It could be understood by the instability of some banks, steep and slippery, which caved in under the imposing weight of animals of several tonnes, not giving them a chance to extricate from this bog and not offering a foothold in case of fall. The profile doesn't seem to result of catastrophic massive death. It rather affected small groups of males or families excluding young mammoths whose lightness helped them escape this trap.

Hot Springs dans le Dakota du Sud est incontestablement l'un des sites les plus riches en vestiges de mammouths in situ jamais mis au jour. Le site daté du Pléistocène supérieur correspond à un ancien marécage issu d'une source artésienne. La source, constamment à $35{ }^{\circ} \mathrm{C}$, était providentielle en période glaciaire pour les animaux qui pouvaient se désaltérer et se repaitre d'une végétation verdoyante typique d'un marécage, et cela en toutes saisons. Toutefois, la source constituait un piège impitoyable pour les animaux qui s'aventuraient dans le lac se terminant en entonnoir dans sa partie submergée. Ainsi, il y a \pm 26000 ans BP (moyenne des datations ${ }^{14} \mathrm{C}$, Laury 1990), nombre d'animaux se sont laissés prendre au piège, essentiellement les mammouths. Afin de comprendre ce phénomène, nous nous sommes attachés à dresser la courbe de mortalité des proboscidiens. Pour ce faire, nous avons attribué à chaque individu une classe d’âge, définie par le rang de chaque molaire, au sein de la série jugale, couplé à son degré d'usure. La révision du profil de mortalité de Mammuthus columbi dressé en 1994, au vu des nouvelles données collectées et présentées ici, indique que le piège a affecté une majorité de sujets adultes. En effet, vingt-deux individus sur une totalité de trente-six identifiés d'après leurs molaires, étaient approximativement âgés de 25 à 38 ans. Le déficit en individus séniles associé au manque de très jeunes mammouths est pour le moins surprenant. Ce profil inhabituel pourrait s'expliquer par l'instabilité de berges abruptes et glissantes se dérobant sous un poids imposant, ne laissant aucune chance aux animaux approchant les cinq tonnes de s'extraire d'un bourbier qui ne leur offrait aucune prise en cas de chute. Il ne semble pas que ce profil résulte de mortalités massives catastrophiques mais plutôt de petits groupes de mâles ou de familles dont les jeunes mammouths, moins lourds, auraient pu réchapper.

\section{INDEX}

Mots-clés: Mammuthus columbi, profil de mortalité, molaires, piège naturel, paléoenvironnement, Pléistocène supérieur, Dakota du Sud, États-Unis

Keywords: Mammuthus columbi, Death profile, Cheek teeth, Natural trap, Paleoenvironment, Upper Pleistocene, South Dakota, United States

\section{AUTHOR}

\section{SOPHIE LOUGUET-LEFEBVRE}

Communauté d'Agglomération du Douaisis - Direction d'Archéologie Préventive, 227, rue Jean Perrin - ZI Dorignies - FR-59500 Douai hypsodonta@gmail.com

HALMA-IPEL - UMR 8164 (CNRS, Lille 3, MCC) - http://halma-ipel.recherche.univ-lille3.fr/

spip.php?article259 